\title{
Recent benthic foraminiferal assemblages from the Celtic Sea (South Western
}

\section{Approaches, NE Atlantic)}

Dorst, Sabine ${ }^{1}$, Schönfeld, Joachim ${ }^{1}$ and Walter, Lilli ${ }^{2}$

${ }^{1}$ GEOMAR Helmholtz Centre for Ocean Research, Wischhofstr. 1-3, 24148 Kiel, Germany

${ }^{2}$ Institute of Geosciences, University of Kiel, Ludewig-Meyn-Str. 10, 24118 Kiel, Germany

Correspondence author: sdorst@geomar.de, phone 4904316002251, fax 4904316002925

\section{Abstract}

The faunal composition and diversity pattern of Recent benthic foraminifera from the shelf and slope of the South Western Approaches (Celtic Sea) were assessed. The sampling stations cover a depth range from 100 to $500 \mathrm{~m}$. A total number of 294 species was recorded, of which 89 were found exclusively in the living fauna and 118 only in the dead assemblage, whereas 87 species were found in both assemblages. The faunal composition revealed a distinct bisection of the living fauna on the shelf. While certain distribution patterns of living dominant species were recognized along a NE-SW trending transect towards the shelf edge, the living fauna changed within small depth intervals and geographic position on the slope. Causes for this structured slope assemblages were probably along-slope currents of varying strengths, as well as variations in topography and bottom sediments. Analyses of population densities and diversity patterns determined high densities along the shelf edge and at one slope station, as well as an increasing diversity with water depth. A comparison with literature data from the same area yields distinct differences in faunal composition on the shelf and slope. The diversity was similar on the shelf, but higher at corresponding stations on the slope. We conclude that the faunal composition was highly influenced by the time and methods of sampling. In order to obtain consistent results in regional studies, all samples 
should be taken in a short time interval and by using the same sampling device. In addition, we depicted the influences of environmental parameters on dead faunal assemblages and their consequences for paleoenvironmental interpretations of fossil foraminiferal assemblages.

\section{Keynotes}

Benthic foraminifera, Diversity, Distribution pattern, Celtic Sea, NE Atlantic

\section{Zusammenfassung}

Im Rahmen dieses Forschungsprojektes wurden die Faunenzusammensetzung und Diversitätsmuster benthischer Foraminiferen vom Schelf und Kontinentalhang der South Western Approaches (Keltische See) ermittelt. Die beprobten Stationen liegen in einem Tiefenbereich von 100 - 500 m. Die statistische Auswertung der Daten ergab eine Gesamtartenzahl von 294, mit 89 lebenden und 118 toten Arten, sowie 87 Arten, die sowohl in der Lebend- als auch in der Totfauna vertreten waren. Die Artenzusammensetzung erbrachte eine deutliche Zweiteilung der Lebendfauna auf dem Schelf. Während sich bestimmte Verteilungsmuster einiger dominanter lebender Arten entlang eines NE-SW Transekts in Richtung der Schelfkante ergaben, zeigte die Lebendfauna am Hang eine starke Strukturierung sowohl innerhalb kurzer Tiefenintervalle als auch bezüglich ihrer geographischen Position an. Gründe hierfür könnten möglicherweise die unterschiedlichen Wassermassen, die in unterschiedlichen Tiefen entlang des oberen Kontinentalhangs strömen, als auch dessen differenzierte Topographie und Sedimentzusammensetzung sein. Die Untersuchung der Siedlungsdichten und Diversitätsmuster zeigte eine hohe Dichte entlang der Schelfkante und an einer Station am Hang, sowie eine kontinuierliche Zunahme der Diversität mit zunehmender Wassertiefe. 
Ein Vergleich mit Literaturdaten aus diesem Gebiet erbrachte deutliche Unterschiede in der Faunenzusammensetzung sowohl auf dem Schelf als auch auf dem Hang. Während sich für den Schelf im Vergleich recht ähnliche Diversitätsmuster ergaben, waren die Diversitäten am Kontinentalhang für nahegelegene Stationen anderer Autoren höher. Wir konnten zeigen, dass der Zeitpunkt und die Methodik der Probennahme einen starken Einfluss auf die Faunenzusamensetzung besitzen. Um konsistente Datensätze zur Diversität in einem regionalen Gebiet erhalten zu können, sollten alle Proben innerhalb einer kurzen Zeitspanne und nach einer einheitlichen Methodik entnommen werden. Weiterhin konnten wir zeigen, welchen Einfluss Umweltparameter auf die Zusammensetzung der Totfauna besitzen, und welche Auswirkungen dies auf die Interpretation des Paläomilieus anhand von fossilen Foraminiferengemeinschaften haben kann.

\section{Schlüsselwörter}

benthische Foraminiferen, Diversität, Verbreitungsmuster, keltische See, Nordostatlantik

\section{Introduction}

\section{Geomorphology}

The study area is located at the South Western Approaches, a region of the Celtic Sea. This shallow marginal sea is situated to the south of Ireland and southwesterly of Great Britain and covers an area of $75000 \mathrm{~km}^{2}$ up to $200 \mathrm{~m}$ water depth (Hardisty 1990). The outer western English Channel and the southern Celtic Sea are known generally as the South Western Approaches (Hamilton 1979). 
The sea floor of the Celtic Sea shelf is characterized by an extensive field of SW-NE trending linear tidal sand ridges between a water depth of $130 \mathrm{~m}$ and the shelf break (Bouysse et al.

1979; Pantin and Evans 1984; Scourse et al. 2009). These ridges are $40-200 \mathrm{~km}$ long and 4 $15 \mathrm{~km}$ wide. They are discrete sedimentary bodies resting on a sub-horizontal erosional surface cut across Lower Pleistocene to Devonian-Carboniferous marine formations (Pantin and Evans 1984; Scourse et al. 2009). Below the shelf break at about $200 \mathrm{~m}$ depth, the $1^{\circ}-4^{\circ}$ steep continental slope leads down to the abyssal plain in water depths ranging from $4200-$ 4400 m (Hamilton 1979; Bourillet et al. 2003). The western continental slope is characterized by terraces with a low gradient (e.g., Goban spur), whereas the southern part of the slope consists of more than 30 NE-SW running submarine canyons in a dendritic pattern (e.g., Shamrock canyon, Blackmud canyon; Hamilton 1979; Bourillet et al. 2003; van Rooij et al. 2007).

\section{Bottom sediments}

Recent sea-floor sediments of the Celtic Sea consist mainly of Pleistocene gravels, sands and clays, as well as biogenous components (skeletal and shell fragments) from organisms living on the shelf (Banner and Culver 1979; Hamilton 1979). In areas affected by strong bottom currents, these sediments move over a pavement of immobile pebbles and shells (Stride 1963; Pantin and Evans 1984). Especially in the South Western Approaches, sediments are successively transported towards the shelf edge, where they may travel down submarine canyons as a grain flow (Stride 1963; Hamilton 1979).

\section{Hydrography}


Sediment transport on the Celtic shelf is characterized mainly by wind and density driven flows, as well as tidal currents and seasonal storm induced waves (Murray et al. 1982; Pingree and LeCann 1989; Huthnance 1995). Because of low water depths, the shelf is characterized by a seasonal thermal stratification of the water column (Austin et al. 2006). During the winter months the water column is well mixed to a depth of $300 \mathrm{~m}$, whereas from April to October it is strongly stratified (Joint et al. 2001).

A slope current flows in northward direction alongside the shelf edge and the upper slope $(<$ 1000 m; Huthnance 1995; White 2007). This slope current occurs together with a wind and density driven cross current on the shelf (White and Bowyer 1997). Contour currents, in depth ranges of $100-450 \mathrm{~m}$ and $450-1000 \mathrm{~m}$, transport northeastern Atlantic water masses to the Norwegian Sea. They reach the highest current velocity in the winter months (Pingree et al. 1999; Friocourt et al. 2007).

\section{Productivity}

The development of the spring bloom in the Celtic Sea depends strongly on the mixing of the water column (Joint et al. 2001). This bloom occurs mainly between the middle of April and the beginning of May (Gowen et al. 1999; Rees et al. 1999; Joint et al. 2001). Over the shelf, phytoplankton production is influenced by changes in nutrient advection at the shelf edge (Pingree et al. 1981, 1982). The phytoplankton species composition varies both annually and geographically and it is influenced by dissolved nutrient ratios as well as vertical mixing events (Martin-Jézéquel and Videau 1992; Van Oostende et al. 2012). The annual surface ocean phytoplankton production at the South Western Approaches is $245 \mathrm{~g} \mathrm{C} \mathrm{m}^{-2} \mathrm{a}^{-1}$. During spring bloom, it may reach $1.4 \mathrm{~g} \mathrm{C} \mathrm{m}^{-2} \mathrm{~d}^{-1}$ (=511 $\mathrm{g} \mathrm{C} \mathrm{m}^{-2} \mathrm{a}^{-1}$ for bloom times; Joint et al. 2001). Phytodetritus is rapidly deposited on the sea floor immediately after the bloom (Rees et al. 1999). On the shelf, it is swept by currents, moves towards the shelf break, and forms 
intermediate and near-bottom nepheloid layers. They spread along density interfaces at mid depth, or descend the continental slope, partially funnelled in canyons (Heussner et al. 1999; Van Weering et al. 2001).

\section{Previous work}

Early studies of benthic foraminifera from the Celtic Sea and western English Channel depicted a correlation between the faunal variations and water depth, sediment type, and tidal and current regimes (Le Calvez 1958; Le Calvez and Boillot 1967; Murray 1970; Murray 1979; Sturrock and Murray 1981; Murray et al. 1982; Weston 1985; Scott et al. 2003). Further investigations of suspended sediment samples showed that small, dead foraminiferal tests $(<200 \mu \mathrm{m})$ were suspended and transported from areas with powerful vertical turbulences and mixing (e.g., English Channel) to areas with a thermally stratified water column (e.g., South Western Approaches; Murray 1970; Murray 1979). Particularly strong bottom currents in the southern Celtic Sea pass over the shelf and lead to deposition of transported tests on the slope (Murray et al. 1982). The intensity of the current systems influences the seasonal stratification on the Celtic shelf. Environmental parameters such as food supply and oxygen concentrations in pore and bottom waters are linked to seasonal stratification and vary from mixed to stratified waters. These parameters are the primary controlling factors on the distribution of benthic foraminiferal assemblages (Weston 1985; Scott et al. 2003).

In a recent compilation study, distribution patterns of common benthic foraminiferal species depicted "oak leaf" shaped mega patchiness on the shelf, suggesting lateral variations in environmental conditions on a $100 \mathrm{~km}$ scale or mirroring non-random sample distribution. A transect through the English Channel suggested an indistinct increase in species richness towards the Celtic Sea. This trend was blurred by large differences in taxonomy, sampling and preparation methods as reported in the literature (Dorst and Schönfeld 2013). 
The aim of our study was to revisit and extend the Channel transect across the shelf to the uppermost slope of the South Western Approaches. For this purpose, samples were taken on a transect perpendicular to the hydrographic front in the outer Channel separating mixed and thermally stratified waters. This will allow us to assess the effect of depth and distance from the Channel entrance on benthic fauna, and to constrain which environmental parameters influence these changes. Samples from other cruises, lying close to the transect were also considered in order to improve the spatial sample resolution of the transect. During the course of the study, it turned out that the influence of the hydrographic front was less distinct and that shelf upwelling and food availability were of greater importance for the benthic faunal assemblages. Following these results, we extended our study and took samples underneath the shelf upwelling zone during the spring bloom in May 2008. Integrating both sample sets will allow describing the foraminiferal response to multiple environmental influences. Such insights should contribute to a better understanding of fossil assemblages and their paleoenvironmental implications. Sample preparation, faunal analyses and taxonomy followed current concepts, facilitating a higher data consistency as among earlier studies (Schönfeld et al. 2012, 2013).

\section{Materials and methods}

\section{Sample and data sources}

The study area is located in the South Western Approaches of the Celtic Sea, southwest of the English Channel between $47^{\circ}$ and $50^{\circ} \mathrm{N}$ (Fig. 1). We investigated 13 surface samples from the shelf and uppermost continental slope between 115 and $467 \mathrm{~m}$ water depth. The samples are broadly aligned along a NE - SW transect, with several samples situated along the NW SE directed shelf break. Faunal data of five adjacent shelf stations of Sturrock and Murray 
(1981) and Murray et al. (1982) were also considered in our analyses (Fig. 1). For these two studies only, the metadata (coordinates, water depth, size fraction, discernation of live and dead specimens, complete quantitative faunal data) were available, and thus allow a comparison with the results of our study. Census data of the living fauna were published as Excel web files (WA-118) by Murray (2006). For the continental slope, faunal data from three stations of Schönfeld and Altenbach (2005) were considered too. The census data were partially published in 2005 (living Uvigerina species only). Herein, we used the complete dataset of living and dead foraminiferal species. Foraminiferal data from Le Calvez (1958), Le Calvez and Boillot (1967), Murray (1970) and Weston (1985) from this area were also considered (Fig. 1).

\section{Methods of sampling}

Samples were taken on three separate cruises in 1995 (FS Thalia), 1997 (R/V Victor Hensen) and 2008 (R/V Belgica; Tab. 1). During the R/V Victor Hensen cruise, a Van Veen grab sampler was used. Samples were preserved and stained in a Rose Bengal/ethanol solution in order to recognize foraminifers living at the time of sampling (Lutze and Altenbach 1991; Murray and Bowser 2000). Samples from the R/V Belgica cruise and the FS Thalia cruise were taken with a NIOZ Haja box corer, also preserved, and stained in ethanol and Rose Bengal (Tab. 1). All samples were taken from the uppermost centimetre of the surface sediment.

Samples of Sturrock and Murray (1981) and Murray et al. (1982) were taken with a Shipek grab sampler (modified to prevent washing of the sample) and preserved in methanol. Samples of Schönfeld and Altenbach (2005) were recovered with a USNEL box corer. Foraminiferal samples were taken from the 0 to $1 \mathrm{~cm}$ interval of the surface sediment, and preserved and stained with a methanol/Rose Bengal solution on collection (Tab. 1). 


\section{Sample preparation}

Samples were carefully washed through stacked $2000 \mu \mathrm{m}$ and $63 \mu \mathrm{m}$ sieves. Residues were dried at $60^{\circ} \mathrm{C}$. In cases when residues were very rich in foraminifers, samples were split with an Otto microsplitter to manageable subsets with a target number of 300 to 400 specimens per census. Splits or residues were further subdivided into different grain-size fractions $(63-125$ $\mu \mathrm{m}, 125-250 \mu \mathrm{m}, 250-400 \mu \mathrm{m}$ and $400-2000 \mu \mathrm{m})$ to facilitate microscopic work. The $>2000 \mu \mathrm{m}$ fraction, consisting of pebbles, sand, and skeletal and shell fragments was examined for attached living foraminifers. Samples were routinely picked dry. Some detritusrich samples were picked wet in order to facilitate microscopic work. Living and dead individuals were recorded separately. All specimens were collected in Plummer cell-slides, sorted at species level, fixed with glue, and counted. The samples and Plummer cells were stored at GEOMAR Helmholtz Centre for Ocean Research Kiel.

Samples of Sturrock and Murray (1981) were reported to have been washed on a $63 \mu \mathrm{m}$ sieve, stained with rose Bengal, washed again on a $63 \mu \mathrm{m}$ sieve and dried at $80^{\circ} \mathrm{C}$. Afterwards the foraminiferids were floated off in trichloroethylene and over 100 living (stained) individuals were counted. All substrates $>4 \mathrm{~mm}$ were examined for attached species. Samples of Murray et al. (1982) were reported to have been stained in a Rose Bengal solution of at least 30 minutes and then were washed on a $76 \mu \mathrm{m}$ sieve. Residues were examined wet for all stained foraminifers.

Samples of Schönfeld and Altenbach (2005) were washed by the second author of the present paper through stacked $2000 \mu \mathrm{m}$ and $63 \mu \mathrm{m}$ sieves. The $>2000 \mu \mathrm{m}$ fraction was examined for attached living foraminifers. Residues were further divided into the $63-250 \mu \mathrm{m}$ and $250-$ $2000 \mu \mathrm{m}$ grain-size fractions. Both, the living (stained) and dead foraminiferal specimens 
were analyzed from the $>250 \mu \mathrm{m}$ fraction by the second author. Their samples and Plummer cells were stored at GEOMAR Helmholtz Centre for Ocean Research Kiel, too.

\section{Taxonomic identification of foraminiferal species}

Foraminiferal species were determined after Phleger and Parker (1951), Parker (1954), Murray (1971), Haynes (1973), and Jones (1994). They were cross-checked with type descriptions of Ellis and Messina (1940) catalogue. Certain arenaceous species were determined after Brönnimann and Whittaker (1983), Brönnimann and Zaninetti (1984), and Brönnimann and Whittaker $(1988,1990)$. Ammonia species were assigned to their molecular types after Hayward et al. (2004).

\section{Results}

Faunal distribution pattern and abundant species

A total number of 294 species were recorded, of which 89 were found exclusively in the living fauna and 118 only in the dead assemblage, whereas 87 species were found in both assemblages. These figures are based on an overall census of 4419 living and 5948 dead specimens. Fifty-nine percent of all species belong to the suborder Rotaliina, $33 \%$ to the suborder Textulariina and $9 \%$ to the suborder Miliolina.

The distribution pattern of living species revealed a bisection in shelf and slope. The shelf is also structured by a proximal and a distal fauna (Fig. 2). The faunal composition was largely consistent within these shelf groups, whereas a strong variation in the living faunas between the individual stations was found on the slope. Dead assemblages showed differences in composition as compared to the living fauna, but the variability in dead assemblages between 
individual stations was lower. In particular, the number of species of the living fauna (28 dominant species) was nearly twice the number of the dead assemblage (15 dominant species). A bisection was recorded between a shelf assemblage (stations $32-36,02$ and 78) and a mainly slope assemblage (stations 37, 49, 50, 06, and 05 and 08; Fig. 3).

Trifarina angulosa and Gavelinopsis praegeri were the most frequent species in the living fauna (Figs. 2, 4a, b). They were recorded as dominant species (one of the five most abundant species in a station) at nine and ten stations, respectively, with a frequency of $5-28 \%$. Trifarina angulosa was recorded up to $340 \mathrm{~m}$ water depth, whereas Gavelinopsis praegeri was found frequently only to the shelf edge at $191 \mathrm{~m}$. Bolivina difformis and Cassidulina obtusa showed distinct distribution pattern on the shelf (Figs. 2, 4a, b). Bolivina difformis was recorded as a frequent species only at stations that were located inside the tidal sand ridges system (Fig. 2). Cassidulina obtusa was recorded as an abundant species at stations situated along the shelf edge (Fig. 2). In addition, Cibicides lobatulus (Fig. 4a, b) was with $36 \%$ the most abundant species only at one station close to Brittany, and its frequency was markedly low $(<5 \%)$ at all other stations. Epistominella vitrea was the most abundant species $(23 \%)$ at the westernmost shelf edge (Fig. 2). This species was also found living at other shelf and slope stations, but with much lower proportions $(\leq 2 \%)$.

The living fauna was different at the slope stations, changing substantially with increasing depth and geographical distance between the stations. In particular, Trifarina angulosa and $G$. praegeri were the first and second ranked species on the shelf edge (station 50), whereas Rotaliammina concava, Reophax curtus, Placopsilina sp., Valvulineria sp. and Melonis barleeanum were the first and second ranked species at the deeper stations (Figs. 2, 4a, b). We used the similarity index of Sanders (1960) to identify the similarities between the living faunal assemblages of the slope stations. Therefore, we compared the relative abundance of taxa between stations 50 and 49, 49 and 37,37 and 06, and 49 and 06 . The similarity index 
decreased from $38 \%$ to $4 \%$, which means that the faunal differences changed significantly with increasing depth and geographical distance between the stations.

We compared the inventory of our most abundant living species at six shelf stations $(32-35$, 05 and 78) with those from adjacent stations reported by Sturrock and Murray (1981) and Murray et al. (1982). They recorded a total number of 61 living species and 587 specimens from five stations. In contrast, the total number of living species at our six stations was 98 and based on an overall census of 2371 specimens. The $\gamma$-diversity was with a Fisher $\alpha$ index of 17 in the literature data and about 21 in our data, not substantially different (Schönfeld et al. 2013). Comparing the dominant species inventory of adjacent stations, we found a match of the same four dominant species (T. angulosa, G. praegeri, C. lobatulus and Spirillina vivipara) for our station 78 and their station 18/166 (Fig. 1). At all other stations, only two species were the same as in our corresponding samples. These species were T. angulosa, $G$. praegeri, Portatrochammina murrayi or C. obtusa, each at respective stations. In addition, $S$. vivipara was recorded as a frequent species in four samples of Sturrock and Murray (1981) and Murray et al. (1982). This species was abundant only in the above mentioned station 78, but less frequent $(<2 \%)$ at the other five stations.

The living fauna at the slope stations $37,49,50$ and 06 were compared with the living fauna from three adjacent stations of Schönfeld and Altenbach (2005). They analyzed the benthic foraminiferal fauna from the $>250 \mu \mathrm{m}$ fraction. No further foraminiferal analyses of the $<250$ $\mu \mathrm{m}$ fraction was made, in order to preserve the authenticity of the reference material of Schönfeld and Altenbach (2005). Therefore, we extracted the faunal data of the $>250 \mu \mathrm{m}$ fraction from our census for the four slope stations. A total number of 38 living species and 172 specimens were recorded. In contrast, 88 living species and 330 specimens were recorded by the other authors. Hence their $\gamma$-diversity with a Fisher $\alpha$ index of 39 was markedly higher than that of 15 in our samples. A consistent species distribution pattern was not found in either sample set. The faunal composition changed significantly with increasing depth. 
However, species of the genus Reophax were recorded dominant at the stations of Schönfeld and Altenbach (2005). On the other hand, R. concava was one of the dominant species at our stations. Comparing the dominant species from similar water depths, only one living species was the same at every station.

Cibicides lobatulus and Spiroplectinella sagittula were the most frequent species in the dead assemblages (Figs. 3, 4a, b). They occurred as dominant with a frequency of $6-39 \%$. Distinct distribution patterns were distinguished for other dominant species. Textularia pseudogramen was recorded as a frequent species only up to $150 \mathrm{~m}$ water depth, whereas it was less abundant $(<5 \%)$ in all other stations (Figs. 3, 4a, b). Bolivina difformis and C. obtusa were found in all stations, but were only recorded as a dominant species along the shelf edge and at station 06. Globocassidulina subglobosa was found to be frequent at all slope stations and at station 05 (Figs. 3, 4a).

The dead assemblage of the $>250 \mu \mathrm{m}$ fraction from slope stations $37,49,50$ and 06 was compared with the dead assemblage of Schönfeld and Altenbach (2005). We determined a total number of 59 dead species, based on 432 specimens, whereas a total number of 73 dead species and 954 specimens were recorded by Schönfeld and Altenbach (2005). The $\gamma-$ diversities were with an index of 18 in each case the same. Cibicides lobatulus, Cibicides refulgens and Cibicidoides sp. were recorded as a dominant species at our stations 49 and 50 and their stations 754 and 755, respectively. At deeper stations, the inventory of the five most abundant species changed completely. Only one dominant species from our station 06 matched with one dominant species from their station 753 . 
In the living fauna, population densities ranged from 12 specimens per $10 \mathrm{~cm}^{3}$ (station 37 ) to 522 specimens per $10 \mathrm{~cm}^{3}$ (station 08 ). The population density was generally highest between $130-180 \mathrm{~m}$ depth (Fig. 5). The number of individuals per $10 \mathrm{~cm}^{3}$ decreased successively on the slope, with exception of station 06 . The number of tests per $10 \mathrm{~cm}^{3}$ in the dead assemblage was highest at station 06, and the lowest number was found at station 49 (Fig. 6). Overall, the number of tests per $10 \mathrm{~cm}^{3}$ was highest along the shelf edge and lowest along the transect on the slope.

Population densities of six stations were compared with densities from adjacent stations of Sturrock and Murray (1981) and Murray et al. (1982; Fig. 1). They found population densities between 60 and 80 individuals per $10 \mathrm{~cm}^{3}$ in their samples, whilst we recorded population densities between 25 and 300 individuals per $10 \mathrm{~cm}^{3}$.

We additionally compared the number of living individuals per $10 \mathrm{~cm}^{3}(>250 \mu \mathrm{m})$ from three stations of Schönfeld and Altenbach (2005), with data from stations 37, 49, 50 and 06 in this study. Population densities were with 11 and 23 individuals per $10 \mathrm{~cm}^{3}$ higher in the samples of Schönfeld and Altenbach (2005) than in samples from this study, where $4-12$ individuals per $10 \mathrm{~cm}^{3}$ were recorded.

To describe and compare the diversity of benthic foraminifera in the study area, we used the Fisher $\alpha$ index, in order to retain consistency with other publications from the NE Atlantic (Fisher et al. 1943; Hayek and Buzas 2013). A distinct bisection of Fisher $\alpha$ indices and water depth was found (Fig. 7). The index of the living fauna showed values between 6 and 15 up to the shelf break. At the deepest stations on the slope, the Fisher $\alpha$ index of the living fauna ranged from 17 to 19 .

Similar indices for the living fauna were found at most stations, when comparing our data with diversity measures as reported by Sturrock and Murray (1981) and Murray et al. (1982). Therefore, the diversity can be considered as being rather uniform in this area (Fig. 7). 
In contrast, the diversity on the slope was significantly different between our stations and the stations of Schönfeld and Altenbach (2005). With indices between 20 and 40, the diversity of the living fauna was much higher in the aforementioned study than in our study $(<10)$.

\section{Correspondence analysis}

Correspondence analysis (CA) is one of the eigenvector methods for exploring large and complex data sets. The analysis produces scatter plots where data with the same or similar properties are shown in a cloud of points in an ordination plot (Hennebert and Lees 1991; Hammer et al. 2001). We applied CA for our samples together with the data of Sturrock and Murray (1981), Murray et al. (1982), and Schönfeld and Altenbach (2005) to identify relationships between samples or faunal assemblages.

CA was undertaken for the dominant living species, which comprise the five ranked species from every station, and which produced the most significant results. Because station 06 had a complete different faunal assemblage, we eliminated this station from the CA. The analysis extracted 11 axes for 23 dominant species from 12 samples. The best discernation of faunal groups was displayed between the two first ranked axes representing $44 \%$ of the total data variability. The station scores inferred three clusters, where stations 37 and 49 from the slope were separated from the other stations by an axis 1 score of 1.2 , and by each other by axis 2 scores (Fig. 8). All other samples derived from the shelf and grouped at axis 2 in a score range from 0.6 to -0.7 . It is therefore conceivable that axis 1 can be interpreted as reflecting water depth. At axis 2, station 08 was situated at the positive score end, whereas station 78 was situated at the negative score end. Thus, axis 2 can be interpreted as reflecting the proximal and distal distribution at the shelf. The species scores inferred to a top left open parabola-like structure (Fig. 9). One or three species were situated at the endpoint and right edge of the parabola. They were dominant in only one station. These species were Epistominella vitrea at 
station 08, Textularia skagerakensis and Placopsilina sp. at station 49, as well as Bolivina variabilis, Reophax curtus and Trochammina squamata at station 37 (Fig. 4a, b). All above mentioned species occurred with low frequencies in other stations, except Reophax curtus. We also carried out CA for all living species and for the living species with a frequency $\geq 2 \%$ and $\geq 5 \%$, together with the data of Sturrock and Murray (1981), Murray et al. (1982), and Schönfeld and Altenbach (2005). No other results were obtained from the CA as compared to the analyses described above.

\section{Discussion}

Distribution pattern of abundant species in the living fauna

The species distribution pattern revealed a bisection in shelf and slope, and a structured shelf with a proximal and distal faunal assemblage. Trifarina angulosa and Gavelinopsis praegeri were the most common species on the shelf and uppermost continental slope. Trifarina angulosa is an epifaunal to shallow infaunal $(0-1.5 \mathrm{~cm}$ sediment depth) free living species and occurs in coarse to gravelly biogenic sands on the shelf and upper slope, where the sediment is under the influence of bottom currents, and where oxic conditions prevail (Mackensen et al. 1993, 1995; Harloff and Mackensen 1997; De Stigter et al. 1998; Schönfeld 2001, 2002; Murray 2006, 2013). Gavelinopsis praegeri is an epifaunal opportunistic (free or attached) living species that is most frequent in coarse pebbly sands of the inner and middle shelf influenced by tidal currents and storm waves (Sturrock and Murray 1981; Murray 2006). In contrast, other abundant species showed distinct distribution patterns. Bolivina difformis was recorded as a frequent species only on the shelf within the tidal sand ridges $(130-200 \mathrm{~m}$, Fig. 10). Different hydrographic conditions inside and outside of the tidal sand ridge field may therefore influence the abundance of this species. Cassidulina obtusa was frequent only 
at stations along the shelf edge. Water masses from the Bay of Biscay run alongside the shelf edge in a NNW direction. This flow is connected with a higher supply of food particles (New 1988; Wollast and Chou 2001) by enhanced primary production (Joint et al. 2001; Van Oostende et al. 2012). This process seems to favor the abundance of C. obtusa. Besides a higher food supply, the quality and composition of organic matter could influence the faunal assemblages. For example, Epistominella vitrea was only abundant at station 08, sampled immediately after the spring bloom (Van Oostende et al. 2012). Epistominella vitrea is an infaunal opportunistic species that prefers a muddy to sandy substrate and which responds to high food availability (Jorissen et al. 1992; Murray 2006; Mendes et al. 2012). Concentration of surface water chlorophyll a was $15 \mathrm{mg} / \mathrm{m}^{2}$ at station 08 at the time of sampling, whereas chlorophyll a concentration ranged between 30 and $40 \mathrm{mg} / \mathrm{m}^{2}$ at stations 02,05 and 06 (Van Oostende et al. 2012). In addition, the phytoplankton community was dominated by coccolithophores and dinoflagellates at station 08 , whereas diatoms were most abundant at the other three stations (Fig. 9 in Van Oostende et al. 2012). This pattern suggests that Epistominella vitrea being better adapted to feed on coccolithophores and dinoflagellates. Different substrates also had an influence on species distribution pattern. Most of the shelf stations were dominated by gravel sands, whereas larger pebbles and shell fragments were retrieved at station 78. Species like Cibicides lobatulus and Spirillina vivipara, which preferred to live epibenthic on different substrates (Sturrock and Murray 1981; Schönfeld 2002; Murray 2006), were frequent at this station. These two species were also found abundant at the adjacent station 18 /166 of Sturrock and Murray (1981). Cassidulina obtusa was found frequently by the aforementioned authors inside the tidal sand ridge system at stations $3 / 13,17 / 152$ and $1 / 1$, although these stations were not situated along the shelf edge (Fig. 10). A reason for this pattern could be the time of sampling combined with a higher food supply. The growth of some species was favored during the summer months, when under a stratified water column a higher organic carbon concentration in the sediment prevailed (Scott 
et al. 2003). Samples of Sturrock and Murray (1981) were taken before the vertical mixing of the water column in autumn. This would offer an explanation for the higher proportion of $C$. obtusa in their samples from the sand ridges.

The living faunas on the slope were significantly different to those on the shelf. Abundant species changed within small depth intervals. Even though our data set is rather sparse in seasonal and spatial coverage, the living fauna evidently showed a high degree of partitioning on the uppermost slope in comparison to the shelf. In this context, different water masses on the continental slope gain relevance. Whilst the North Atlantic Current moves in a SE direction along the shelf edge, underlying water masses of the slope current flow in a northward direction (Van Aken 2001; Friocourt et al. 2007). Nutrient inputs variable by lateral advection, timing, and composition at specific depth intervals are therefore important in establishing habitats for different species on the upper slope. As on the shelf, different substrates probably also influenced the occurrence of certain species. At station 06, the sediment was a very fine quartz-rich sand, whereas a coarser sand with abundant shell detritus was found at the other stations. Completely different species were abundant at station 06 , and were found neither living nor dead at the other stations (e.g. Melonis barleeanum). Besides the influence of different slope currents at different depths, the time of sampling could influence the faunal assemblages. Samples of Schönfeld and Altenbach (2005) were taken in July, whereas our samples were taken at the beginning of April and May (Tab. 1). Only one positive match of a frequent species $>250 \mu \mathrm{m}$ was recognized between the three stations of Schönfeld and Altenbach (2005) and our four slope stations. Most of these abundant species lived epifaunal and attached onto hard substrates (Cibicides lobatulus, Placopsilina sp. and Trochammina squamata). 
The abundant species of the dead assemblage were significantly different from the living fauna, but occurrence patterns were more consistent within the dead assemblages. A distinct distribution pattern as seen in the living fauna on the shelf was not recognized. However, Bolivina difformis and Cassidulina obtusa were only common on and along the shelf edge, as well as at station 06. Total foraminiferal assemblages were analyzed by Le Calvez (1958) close to stations 05 and 08 from this study. Bolivina difformis and C. obtusa were not observed, but $C$. crassa and C. laevigata were found in this area. It is conceivable that a taxonomic misidentification of $C$. crassa and $C$. laevigata accounts for this difference. In particular, shape and size of $C$. crassa and C. obtusa are very similar. High percentages of Cibicides lobatulus and Spiroplectinella sagittula were found in almost all samples. Both species were also recorded in the living fauna, but with a frequency of $<10 \%$. They were also reported from adjacent stations of Le Calvez (1958) and Le Calvez and Boillot (1967) from the outer western English Channel, as well as along the shelf break in samples of Le Calvez (1958) and Murray (1970). Both species were recorded as frequent species (>10\%) in dead assemblages of the English Channel, Bristol Channel and the northern Celtic Sea (Murray 1970; Murray 1979). The high abundance of S. sagittula in the dead assemblage is due to concentration over a long period of time, as the tests are robust and withstand destruction (Sturrock and Murray 1981; Murray et al. 1982). In addition, mixing of assemblages and postmortem transport of small foraminiferal tests from the English Channel and Bristol Channel to the W and SW of the Western Approaches resulted from near-bottom residual flows of suspended sediment (Murray 1970; Murray 1979; Sturrock and Murray 1981; Murray et al. 1982). Together with gale-force winds in the late autumn and winter, the sediment suspension may pass over the shelf and lead to deposition of transported tests on the slope (Murray et al. 1982). These hydrographic processes could explain the distribution of $C$. lobatulus and S. sagittula from the shelf to the slope. Furthermore, a decrease in abundance 
from the shelf to the slope samples was observed for both species. This decrease is maybe linked with the test size (generally $>125 \mu \mathrm{m}$ ) and thus reflects a decline in transport over long distances.

The dead assemblages from the slope differed less among each other in terms of the abundant species. Species of the suborder Textulariina were not frequent on the slope, except $S$. sagittula. Most Textulariina species had a large test size and were maybe too heavy to be thrown into suspension and transported over the shelf edge. There were fewer differences in frequent species at the slope stations, in comparison to the living fauna. The distribution pattern of the dominant slope species in the dead assemblages were similar, especially between stations 50 and 06, and 37 and 49. Much more consistency in the dead assemblages in comparison to the living one was noted between our dominant species and dominant species of Schönfeld and Altenbach (2005). Mainly species of the genera Cibicides and Cibicidoides of a size fraction $>250 \mu \mathrm{m}$ were recorded dominant up to $500 \mathrm{~m}$ water depth at our stations and at two stations of the aforementioned authors. At greater depths (station 753, $684 \mathrm{~m}$ ), the dead assemblage changed completely, even though frequent species of the dead assemblage were similar to frequent species of the living fauna.

\section{Paleoenvironmental implications}

In this study, we demonstrated the influences of hydrographic processes on dead foraminiferal assemblages. As such, the question about the significance of fossil assemblages for sound paleoenvironmental interpretations arises. For instance, analyses of Eocene benthic foraminiferal assemblages of the western English Channel showed likewise a homogeneous distribution pattern (Wright and Murray 1972; Murray and Wright 1974). Species with a porcelaneous and hyaline test structure were most frequent, whereas species with an 
agglutinated test were rare. This assemblage composition suggested an environment ranging from a shallow, nearshore hyposaline shelf sea to a hypersaline lagoon (Wright and Murray 1972). In our samples, however, abundances of agglutinated species were about $20 \%$ lower in the dead assemblages as compared to the living fauna, probably due to destruction during transport processes. In addition, 89 of 294 species were only found in the living fauna. Most of these species had an agglutinated test, and their proportion in a sample was between $4 \%$ and $54 \%$. Fossil foraminiferal assemblages from the western English Channel were generally dominated by robust taxa of Rotaliina and Miliolina. A similar spectrum of abundant, robust Rotaliina and Miliolina was reported from Oligocene deposits of northern Germany. This faunal composition provided evidences for a high-energy costal depositional environment (Nuglisch and Spiegler 1991). Generally, it has been recognized that fossil foraminifera showed no significant lateral variability. Homogenization by sediment redistribution and bioturbation were considered as main attenuated processes. This view has been challenged by an inhomogeneous lateral distribution pattern in fossil foraminiferal assemblages, similar to meter-scale patchiness documented from the living fauna (Scott 1958; Smith and Buzas 1986).

\section{Population density and diversity}

Analysis of the population density and diversity patterns of the living fauna revealed distinct regional differences on the shelf and slope. The outer shelf of the Celtic Sea is covered by SW-NE trending linear tidal sand ridges. Most of our shelf stations were located in this area and some stations were likely situated on these sand ridges (Fig. 10), as reflected by a lower water depth at stations 34 and 02 (Tab. 1). The ridges are $20-50 \mathrm{~m}$ high (Bouysse et al. 1976; Belderson et al. 1986) and stations 34 and 02 had a $20-50 \mathrm{~m}$ lower water depth as in the vicinity, as inferred from bathymetrical charts. In addition, samples 34, 02 and 08 had the 
same sediment composition with a high proportion of rounded quartz grains and pebbles, whereas station 08 was likely situated at the fold side of a sand ridge as stations 35 and 36, and not on the top of the ridge (Fig. 10). On the other hand, the sand-fraction of samples 35 and 36 was dominated by shell fragments. Comparing the population density of the living fauna on the shelf, densities were highest at stations 33, 05, 08 and 78 with over 100 individuals $/ 10 \mathrm{~cm}^{3}$. Lowest population densities on the shelf were observed in the transect samples, with the exception of sample 33. Possible reasons appeared to be not the sediment composition or the position of the station with reference to water turbulence, but the time and method of sampling. Transect samples were collected with a grab sampler at the beginning of April, whereas samples $02,05,08$ and 78 were collected with a box corer at the beginning of May and at the end of October, respectively (Tab. 1). A box corer is designed to retrieve a well-preserved sediment surface, whereas a grab sampler is not intended to maintain the integrity of near-surface sediments accurately. Some sediment may be washed out when the grab does not close correctly (Schönfeld 2012). The transect samples were collected before the spring bloom, which was constrained for the adjacent Irish Sea to have developed in the middle of April (Gowen et al. 1999), and therefore at a time of lower food supply. The 2008 samples of the Belgica cruise were collected during times of high primary production immediately after the spring bloom, as indicated by satellite data and chlorophyll a measurements (Van Oostende et al. 2012). Therefore, population densities were higher at the 2008 stations.

The Fisher $\alpha$ index yields a similar pattern of the living fauna on the shelf. The diversity was higher at the 2008 stations than at the 1997 stations, except station 33. Possible reasons for higher diversity could be the same as reasons given for population densities above. For example, stations 36 and 02 were situated close together at a tidal sand ridge near the shelf edge, but diversity was twice as high at station 02 compared to station 36 . A comparison with 
samples of Sturrock and Murray (1981) and Murray et al. (1982) showed different results for the population density and the Fisher $\alpha$ index. While the diversity was almost the same, the population density in our six adjacent stations was higher than in the stations of aforementioned authors. In addition, the faunal similarity was under $50 \%$ between corresponding samples. The time of sampling could be a reason for the lower population densities in the samples of Sturrock and Murray (1981). The samples may have been collected at a time of lower food supply. Additionally, the time period between their sample collection and the collection of our samples represents $20-30$ years. In this time period, it is probable that long-time changes in faunal assemblage composition occurred in this area.

The development of trawling at the end of the 1990s could have led to a change in benthic faunal composition. High trawling activity affects the oxygen content in surface bottom sediments and disturbs benthic foraminiferal habitats (Trimmer et al. 2005). This does not appear to have reduced the species number (similar indices), but could have left an impact in the faunal composition.

The upper slope established various habitats in different depth intervals probably induced by different slope currents. Favorable conditions could have led to stronger reproduction and a rich benthic foraminiferal fauna at station 06 . This case is also confirmed by the highest Fisher $\alpha$ index at station 06 . Comparing the diversity pattern of our four slope stations $(37,49$, 50 and 06) and the three stations (753, 754 and 755) of Schönfeld and Altenbach (2005) revealed differences in the population densities, as well as the Fisher $\alpha$ index. Causes for the higher population densities and Fisher $\alpha$ indices of the aforementioned authors could be a higher nutrient supply, due to the station location and the time of sampling. Stations of Schönfeld and Altenbach (2005) were located between two canyons, where it is possible that food particles from intermediate nepheloid layers were trapped. In addition, their samples were taken in beginning of July when a higher phytodetritus supply prevailed due to the spring bloom two months previously. 


\section{Conclusion}

Analysis and comparison of benthic foraminiferal assemblages from the shelf and slope of the Celtic Sea revealed an increase in diversity from the shelf to the continental slope. Highest diversities were determined at the slope and at those shelf stations, which were sampled in May. Such higher diversities were likely promoted by a higher food supply, in response to the timing of the spring bloom. Faunal assemblages on the shelf were more consistent than on the slope, indicating extensive sediment redeposition. The slope fauna was more structured due to the different topography, bottom sediments and specific hydrographical conditions. The faunal composition therefore changed within small depth intervals and geographic position. The comparison of our stations with corresponding stations from earlier studies in the same area revealed major differences in the benthic foraminiferal assemblages, both on the shelf and on the slope. These differences were more likely due to the time and method of sampling than forced by environmental parameters. This leads to the conclusive recommendation that once consistent results in regional studies are required, all samples should be taken within a short period and with the same sampling device. In addition, our analyses of Recent dead foraminiferal assemblages could demonstrate the influences of a high-energy environment on a faunal composition, e.g., loss of arenaceous species, increase of robust miliolids, and a lateral homogenisation in assemblage compositions. These constraints may facilitate a better interpretation of palaeoenvironments from fossil foraminiferal assemblages.

\section{Acknowledgements}

Samples of R/V Victor Hensen cruise VH97 and of FS Thalia cruise were provided by André Freiwald, Senckenberg Wilhelmshaven and Beate Bader, Harstad, respectively. Sampling on 
R/V Belgica cruise BG08/12a was done by Julia Langenbacher, Kiel. We acknowledge the help of Lei Chou, Université libre de Bruxelles for providing ship time for sea floor sampling on this cruise. The second author (J. Schönfeld) acknowledges the help of Captain Walter Baschek as officer on watch and his crew with box-corer operations at the Brittany margin during R/V Poseidon cruise PO201/10. Holger Kühl, Kiel is thanked for help during sampling and Lea Wiser, München is thanked for preparation of foraminifera. Wolfgang Kuhnt and Birgit Mohr, University of Kiel are thanked for help with preparation of microscope and SEM photographs, respectively.

We are also grateful to John W. Murray, Southampton for providing metadata of his shelf samples, as well as to the editor Oliver Rauhut and to anonymous reviewers for their useful and constructive comments. Nicholas Fraser, University of Kiel scrutinized the manuscript. This work was funded by the German Research Foundation; grant number SCHO 605/9-1.

\section{References}

Austin, W.E.N., A. G. Cage, and J.D. Scourse. 2006. Mid-latitude shelf seas: a NW European perspective on the seasonal dynamics of temperature, salinity and oxygen isotopes. The Holocene 16: 937-947.

Banner, F.T., and S.J. Culver. 1979. Sediments of the North-Western European Shelf. In The North-West European Shelf Seas: the Sea Bed and the Sea in Motion I. Geology and

Sedimentology, eds. Banner, F.T., M.B. Collins, and K.S. Massie, 271-300. Amsterdam: Elsevier Oceanography Series 24 A. 
Belderson, R.H., R.D. Pingree, and D.K. Griffiths. 1986. Low sea-level tidal origin of Celtic Sea sand banks - Evidence from numerical modelling of $\mathrm{M}_{2}$ tidal streams. Marine Geology 73: $99-108$.

Bourillet, J.-F., J.-Y. Reynaud, A. Baltzer, and S. Zaragosi. 2003. The 'Fleuve Manche': the submarine sedimentary features from the outer shelf to the deep-sea fans. Journal of Quaternary Science 18: 261-282.

Bouysse, P., R. Horn, F. Lapierre, and F. Le Lann. 1976. Etude des grands bancs de sable du sudest de la mer Celtique. Marine Geology 20: 251-275.

Bouysse, P., F. Le Lann, and G. Scolari. 1979. Les sediments superficiels des Approaches Occidentales de la Manche. Marine Geology 29: 107-135.

Brönnimann, P., and J.E. Whittaker. 1983. A lectotype for Deuterammina (Deuterammina) rotaliformis (Heron-Allen and Earland) and new trochamminids from E Ireland (Protozoa: Foraminiferida). Bulletin of the British Museum (Natural History). Zoology 45: 347-358.

Brönnimann, P., and J.E. Whittaker. 1988. The Trochamminacea of the Discovery reports. A review of the Trochamminacea (Protozoa: Foraminiferida) described from South Atlantic and Antarctic waters by Heron-Allen and Earland (1932) and Earland (1933, 1934, 1936), 152. London: British Museum (Natural History).

Brönnimann, P., and J.E. Whittaker. 1990. Revision of the Trochamminacea and Remaneicacea of the Plymouth District, S.W. England, described by Heron-Allen and Earland (1930). In Paleoecology, Biostratigraphy, Paleoceanography and Taxonomy of agglutinated 
foraminifera, eds. Hemleben, C., M.A. Kaminski, W. Kuhnt, and D.B. Scott, 105-137.

Dordrecht: NATO ASI Series, Series C: Mathematical and Physical Sciences 327.

Brönnimann, P., and L. Zaninetti. 1984. Agglutinated foraminifera mainly Trochamminacea from the Baia de Sepetiba, near Rio de Janeiro, Brazil. Revue de Paléobiologie 3: 63-115.

De Stigter, H.C., F.J. Jorissen, and G.J. Van der Zwaan. 1998. Bathymetric distribution and microhabitat partitioning of live (Rose Bengal stained) Benthic Foraminifera along a shelf to bathyal transect in the southern Adriatic Sea. Journal of Foraminiferal Research 28: 40-65.

Dorst, S., and J. Schönfeld. 2013. Diversity of benthic foraminifera on the shelf and slope of the NE Atlantic: Analysis of datasets. Journal of Foraminiferal Research 43: 238-254.

Ellis, B.F., and A. Messina. 1940. Cataloque of foraminifera. New York: Micropaleontology Press, http://www.micropress.org.

Fisher, R.A., A.S. Corbet, and C.B. Williams. 1943. The relation between the number of species and the number of individuals in a random sample of an animal population. Journal of Animal Ecology 12: 42-58.

Friocourt, Y., B. Levier, S. Speich, B. Blanke, and S.S. Drijfhout. 2007. A regional numerical ocean model of the circulation in the Bay of Biscay. Journal of Geophysical Research 112: $1-19$. 
Gowen, R.J., G. McCullough, G.S. Kleppel, L. Houchin, and P. Elliott. 1999. Are copepods important grazers of the spring phytoplankton bloom in the western Irish Sea?. Journal of Plankton Research 21: 465-483.

Hamilton, D. 1979. The geology of the English Channel, South Celtic Sea and continental margin, South Western Approaches. In The North-West European Shelf Seas: the Sea Bed and the Sea in Motion I. Geology and Sedimentology, eds. Banner, F.T., M.B. Collins, and K.S. Massie, 61-87. Amsterdam: Elsevier Oceanography Series 24 A.

Hammer, Ø., D.A.T. Harper, and P.D. Ryan. 2001. Past: Paleontological Statistics Software Package for Education and Data Analysis. Palaeontologia Electronica 4: 1-9. http://palaeoelectronica.org/2001_1/past/issue1_01.htm.

Hardisty, J. 1990. The British Seas: An introduction to the oceanography and resources of the north-west European continental shelf, 272. London: Routledge.

Harloff, J., and A. Mackensen. 1997. Recent benthic foraminiferal associations and ecology of the Scotia Sea and Argentine Basin. Marine Micropaleontology 31: 1-29.

Hayek, L.-A.C., and M.A. Buzas. 2013. On the proper and efficient use of diversity measures with individual field samples. Journal of Foraminiferal Research 43: 305-313.

Haynes, J.R. 1973. Cardigan Bay Recent Foraminifera (Cruises of the R.V. Antur, 1962 1964). Bulletin of the British Museum (Natural History) Zoology Supplement 4: 1-245. 
Hayward, B.W., M. Holzmann, R. Grenfell, J. Pawlowski, and C.M. Triggs. 2004.

Morphological distinction of molecular types in Ammonia - towards a taxonomic revision of the world's most commonly misidentified foraminifera. Marine Micropaleontology 50: $237-271$.

Hennebert, M., and A. Lees. 1991. Environmental gradients in carbonate sediments and rocks detected by correspondence analysis: examples from the Recent of Norway and the Dinantian of southwest England. Sedimentology 38: 623-642.

Heussner, S., X.D. de Madron, O. Radakovitch, L. Beaufort, P.E. Biscaye, J. Carbonne, N. Delsaut, H. Etcheber, and A. Monaco. 1999. Spatial and temporal patterns of downward particle fluxes on the continental slope of the Bay of Biscay (northeastern Atlantic). Deep-Sea Research II 46: 2101-2146.

Huthnance, J.M. 1995. Circulation, exchange and water masses at the ocean margin: the role of physical processes at the shelf edge. Progress in Oceanography 35: 353-431.

Joint, I., R. Wollast, L. Chou, S. Batten, M. Elskens, E. Edwards, A. Hirst, P. Burkill, S. Groom, S. Gibb, A. Miller, D. Hydes, F. Dehairs, A. Antia, R. Barlow, A. Rees, A. Pomroy, U. Brockmann, D. Cummings, R. Lampitt, M. Loijens, F. Mantoura, P. Miller, T. Raabe, X. Alvarez-Salgado, C. Stelfox, and J. Woolfenden. 2001. Pelagic production at the Celtic Sea shelf break. Deep-Sea Research II 48: 3049-3081.

Jones, R.W. 1994. The Challenger Foraminifera, 149. Hongkong: Oxford University Press. 
Jorissen, F.J., D.M. Barmawidjaja, S. Puskaric, and G.J. van der Zwaan. 1992. Vertical distribution of benthic foraminifera in the northern Adriatic Sea: The relation with the organic flux. Marine Micropaleontology 19: 131-146.

Le Calvez, Y. 1958. Les Foraminifères de la mer celtique. Revue des Travaux de l'Institut des Pêches Maritimes 22: 146-209.

Le Calvez, Y., and G. Boillot. 1967. Étude des Foraminifères contenus dans les sédiments actuels de la Manche Occidentale. Revue de Géographie Physique et de Géologie dynamique 2, IX, Fasc. 5: 391-408.

Lutze, G.F., and A.V. Altenbach. 1991. Technik und Signifikanz der Lebendfärbung benthischer Foraminiferen in Bengalrot. Geologisches Jahrbuch Reihe A, 128: 251-265.

Mackensen, A., D.K. Fütterer, H. Grobe, and G. Schmiedl. 1993. Benthic foraminiferal assemblages from the South Atlantic Polar Front region between 35 and $57^{\circ} \mathrm{S}$ : distribution, ecology and fossilization potential. Marine Micropaleontology 22: 33-69.

Mackensen, A., G. Schmiedl, J. Harloff, and M. Giese. 1995. Deep-sea foraminifera in the South Atlantic Ocean. Micropaleontology 41: 342-358.

Martin-Jézéquel, V., and C. Videau. 1992. Phytoplankton and bacteria over the transient area of the continental slope of the Celtic Sea in spring. I. Vertical distribution and productivity. Marine Ecology Progress Series 85: 289-301. 
Mendes, I., J.A. Dias, J. Schönfeld, and Ó Ferreira. 2012. Distribution of living benthic foraminifera on the northern Gulf of Cadiz continental shelf. Journal of Foraminiferal Research 42: 18-38.

Murray, J.W. 1970. Foraminifers of the western approaches to the English Channel. Micropaleontology 16: 471-485.

Murray, J.W. 1971. An Atlas of British Recent Foraminiferids, 244. London: Heinemann Educational Books.

Murray, J.W. 1979. Recent benthic foraminiferids of the Celtic Sea. Journal of Foraminiferal Research 9: 193-209.

Murray, J.W. 2006. Ecology and application of benthic foraminifera, 438. Cambridge: Cambridge University Press.

Murray, J.W. 2013. Living benthic foraminifera: biogeographical distributions and the significance of rare morphospecies. Journal of Micropalaeontology 32: 1-58.

Murray, J.W., and S. Bowser. 2000. Mortality, protoplasm decay rate, and reliability of staining techniques to recognize 'living' foraminifera: A review. Journal of Foraminiferal Research 30: 66-70.

Murray, J.W., S. Sturrock, and J. Weston. 1982. Suspended load transport of foraminiferal tests in a tide-and wave-swept sea. Journal of Foraminiferal Research 12: 51-65. 
Murray, J.W., and C.A. Wright. 1974. Palaeogene Foraminiferida and palaeoecology, Hampshire and Paris Basins and the English Channel. Special Papers in Palaeontology 14: 1129.

Nuglisch, K., and D. Spiegler. 1991. Die Foraminiferen der Typ-Lokalität Latdorf (NordDeutschland, Unter-Oligozän). Geologisches Jahrbuch A128: 179-229.

New, L. 1988. Internal tidal mixing in the Bay of Biscay. Deep-Sea Research 35: 691-709.

Pantin, H.M., and C.D.R. Evans. 1984. The Quaternary history of the central and southwestern Celtic Sea. Marine Geology 57: 259-293.

Parker, F.L. 1954. Distribution of the Foraminifera in the northeastern Gulf of Mexico. Bulletin of the Museum of Comparative Zoology 111: 453-588.

Phleger, F.B., and F.L. Parker. 1951. Ecology of foraminifera, Northwest Gulf of Mexico, Part II - foraminifera species. Memoir - The Geological Society of America 46: 1-64.

Pingree, R.D., and B. Le Cann. 1989. Celtic and Armorican slope and shelf residual currents. Progress in Oceanography 23: 303-338.

Pingree, R.D., G.T. Mardell, and D.E. Cartwright. 1981. Slope turbulence, internal waves and phytoplankton growth at the Celtic Sea shelf-break. Philosophical Transactions of the Royal Society of London A 302: 663-682. 
Pingree, R.D., G.T. Mardell, P.M. Holligan, D.K. Griffiths, and J. Smithers. 1982. Celtic Sea and Armorican current structure and the vertical distributions of temperature and chlorophyll. Continental Shelf Research 1: 99-116.

Pingree, R.D., B. Sinha, and C.R. Griffiths. 1999. Seasonality of the European slope current (Goban Spur) and ocean margin exchange. Continental Shelf Research 19: 929-975.

Rees, A.P., I. Joint, and K.M. Donald. 1999. Early spring bloom phytoplankton-nutrient dynamics at the Celtic Sea Shelf Edge. Deep-Sea Research I 46: 483-510.

Sanders, H.L. 1960. Benthic studies in Buzzards Bay III. The structure of the soft-bottom community. Limnology and Oceanography 5: 138-153.

Schönfeld, J. 2001. Benthic foraminifera and pore-water oxygen profiles: a re-assessment of species boundary conditions at the western Iberian margin. Journal of Foraminiferal Research 31: 86-107.

Schönfeld, J. 2002. Recent benthic foraminiferal assemblages in deep high-energy environments from the Gulf of Cadiz (Spain). Marine Micropaleontology 44: 141-162.

Schönfeld, J. 2012. History and development of methods in Recent benthic foraminiferal studies. Journal of Micropalaeontology 31: 53-72.

Schönfeld, J., and A.V. Altenbach. 2005. Late glacial to recent distribution pattern of deepwater Uvigerina species in the north-eastern Atlantic. Marine Micropaleontology 57: 1-24. 
Schönfeld, J., E. Alve, E. Geslin, F. Jorissen, S. Korsun, S. Spezzaferri, and Members of the FOBIMO group. 2012. The FOBIMO (FOraminiferal BIo-MOnitoring) initiative - Towards a standardised protocol for soft-bottom benthic foraminiferal monitoring studies. Marine Micropalaeontology 94-95: 1-13.

Schönfeld, J., E. Golikova, S. Korsun, and S. Spezzaferri. 2013. The Helgoland Experiment assessing the influence of methodologies on Recent benthic foraminiferal assemblage composition. Journal of Micropalaeontology 32: 161-182.

Scott, G.H. 1958. Distribution of populations of fossil Foraminifera. New Zealand Journal of Geology and Geophysics 1: 474-484.

Scott, G.A., J.D. Scourse, and W.E.N. Austin. 2003. The distribution of benthic foraminifera in the Celtic Sea: The significance of seasonal stratification. Journal of Foraminiferal Research 33: 32-61.

Scourse, J., K. Uehara, and A. Wainwright. 2009. Celtic Sea linear tidal sand ridges, the Irish Sea Ice Stream and the Fleuve Manche: Palaeotidal modelling of a transitional passive margin depositional system. Marine Geology 259: 102-111.

Smith, R.K., and M.A. Buzas. 1986. Micodistribution of Foraminifera in a Single Bed of the Monterey Formation, Monterey County, California. Smithsonian Contributions to Paleobiology 60: 1-33.

Stride, A.H. 1963. Current-swept sea floors near the southern half of Great Britain. Quarterly Journal of the Geological Society 119: 175-197. 
Sturrock, S., and J.W. Murray. 1981. Comparison of low energy and high energy marine middle shelf foraminiferal faunas, Celtic Sea and western English channel. In Microfossils from recent and fossil shelf seas, eds. J.W. Neale, and M.D. Brasier, M.D., 250-260. Chichester: Ellis Horwood.

Trimmer, M., J. Petersen, D.B. Sivyer, C. Mills, E. Young, and E.R. Parker. 2005. Impact of long-term benthic trawl disturbance on sediment sorting and biogeochemistry in the southern North Sea. Marine Ecology Progress Series 298: 79-94.

Van Aken, H.M. 2001. The hydrography of the mid-latitude Northeast Atlantic Ocean - Part III: the subducted thermocline water mass. Deep Sea Research I: Oceanographic Research Papers 48: 237-267.

Van Oostende, N., J. Harlay, B. Vanelslander, L. Chou, W. Vyverman, and K. Sabbe. 2012. Phytoplankton community dynamics during late spring coccolithophore blooms at the continental margin of the Celtic Sea (North East Atlantic, 2006 -2008). Progress in Oceanography 104: 1-16.

Van Rooij, D., D. Blamart, T. Richter, A. Wheeler, M. Kozachenko, and J.-P. Henriet. 2007. Quaternary sediment dynamics in the Belgica mound province, Porcupine Seabight: icerafting events and contour current processes. International Journal of Earth Sciences (Geologische Rundschau) 96: 121-140.

Van Weering, T.C.E., H.C. De Stigter, W. Balzer, E.H.G. Epping, G. Graf, I.R. Hall, W. Helder, A. Khripounoff, L. Lohse, I.N. McCave, L. Thomsen, and A. Vangriesheim. 2001. 
Benthic dynamics and carbon fluxes on the NW European continental margin. Deep-Sea Research II 48: 3191-3221.

Weston, J.F. 1985. Comparison between recent benthic foraminiferal faunas of the Porcupine Seabight and Western Approaches Continental Slope. Journal of Micropalaeontology 4: $165-183$.

White, M. 2007. Benthic dynamics at the carbonate mound regions of the Porcupine Seabight continental margin. International Journal of Earth Sciences (Geologische Rundschau) 96: $1-9$.

White, M., and P. Bowyer. 1997. The shelf-edge current north-west of Ireland. Annales Geophysicae 15: 1076-1083.

Wollast, R., and L. Chou. 2001. The carbon cycle at the ocean margin in the northern Gulf of Biscay. Deep-Sea Research II 48: 3265-3293.

Wright, C.A., and J.W. Murray. 1972. Comparisons of modern and Palaogene foraminiferid distributions and their environmental implications. Mémoires du Bureau de Recherches Géologiques et Minières 79: 87-96.

\section{Appendix 1}

Taxonomic references of benthic foraminiferal species reported in this study, as well as those of Sturrock and Murray (1981), Murray et al. (1982), and Schönfeld and Altenbach (2005). 
This appendix can be found at OceanRep (GEOMAR_Publications Database; http://oceanrep.geomar.de/24635/).

\section{Appendix 2}

Foraminiferal census data reported in this study, as well as those of Sturrock and Murray (1981), Murray et al. (1982), and Schönfeld and Altenbach (2005). This appendix can be found at OceanRep (GEOMAR_Publications Database; http://oceanrep.geomar.de/24635/).

\section{Table captions}

Table 1 Metadata of stations from this study and Sturrock and Murray (1981), Murray et al. (1982), and Schönfeld and Altenbach (2005). Bold numbers were used as abbreviations of the station numbers in the text and figures.

\section{Figure captions}

Fig. 1 Geographical position of our stations (circles) and corresponding stations of other authors, squares: stations of Sturrock and Murray (1981) and Murray et al. (1982), triangles: stations of Schönfeld and Altenbach (2005), diamonds: stations of Le Calvez (1958), Le Calvez and Boillot (1967), Murray (1970) and Weston (1985)

Fig. 2 Station map with proportions of dominant living species

Fig. 3 Station map with proportions of dominant dead species 
Fig. 4a SEM photographs of abundant species; a Trifarina angulosa; b, c Gavelinopsis praegeri, dorsal and ventral view; d Bolivina difformis; e Spiroplectinella sagittula; $\mathbf{f}$ Cassidulina obtusa; $\mathbf{g}, \mathbf{h}$ Cibicides lobatulus, ventral and dorsal view; i, j Trochammina squamata, ventral and dorsal view; k, l Rotaliammina concava, ventral and dorsal view; m Textularia pseudogramen; n, o Portatrochammina murrayi, ventral and dorsal view; p, q Globocassidulina subglobosa, dorsal and ventral view; r Reophax curtus; photographs were taken with a CamScan 44/EDX scanning electron microscope

Fig. 4b Optical microscope photographs of abundant species; a Reophax curtus; b Textularia pseudogramen; c, d Cassidulina obtusa, ventral and dorsal; e, f Rotaliammina concava, dorsal and ventral; $\mathbf{g}$ Trifarina angulosa $\mathbf{h}$ Bolivina difformis; $\mathbf{i}, \mathbf{j}$ Trochammina squamata, ventral and dorsal; k, l Cibicides lobatulus, dorsal and ventral; m, n Portatrochammina murrayi, dorsal and ventral; o, p Epistominella vitrea, dorsal and ventral; q Spiroplectinella sagittula; r, s Gavelinopsis praegeri, dorsal and ventral; photographs were taken with a Keyence VHX -700 FD camera

Fig. 5 Population densities of the living fauna per $10 \mathrm{~cm}^{3}$

Fig. 6 Number of individuals per $10 \mathrm{~cm}^{3}$ of the dead assemblages. Please note the different scale at the y-axis compared to Fig. 5

Fig. 7 Fisher $\alpha$ index of the living fauna (gray circles) and dead assemblages (white circles) as a function of water depth; gray squares: Fisher $\alpha$ index of the living fauna of Sturrock and Murray (1981) and Murray et al. (1982) 
Fig. 8 Correspondence analysis of the living dominant species without station 06; sample distribution

Fig. 9 Correspondence analysis of the living dominant species without station 06; species distribution

Fig. 10 Location map showing Celtic Sea linear tidal sand ridges; circles: stations of this study, squares: stations of Sturrock and Murray (1981) and Murray et al. (1982), triangles: stations of Schönfeld and Altenbach (2005); modified from Scourse et al. (2009) 


\section{Dorst, Table 1}

\begin{tabular}{|c|c|c|c|c|c|c|c|}
\hline Studies & Cruise & Station & Sampling date & Latitude & Longitude & Depth (m) & Device \\
\hline \multirow{13}{*}{ This study } & \multirow{8}{*}{$\begin{array}{c}\mathrm{R} / \mathrm{V} \\
\text { Victor } \\
\text { Hensen }\end{array}$} & VH-97-32D & 04.04 .1997 & $49^{\circ} 00.03^{\prime} \mathrm{N}$ & $5^{\circ} 56.55^{\prime} \mathrm{W}$ & 115 & Van Veen grab \\
\hline & & VH-97-33D & 04.04 .1997 & $48^{\circ} 44.33^{\prime} \mathrm{N}$ & $6^{\circ} 12.33^{\prime} \mathrm{W}$ & 131 & Van Veen grab \\
\hline & & VH-97-34 & 04.04 .1997 & $48^{\circ} 27.05^{\prime} \mathrm{N}$ & $6^{\circ} 26.82^{\prime} \mathrm{W}$ & 116 & Van Veen grab \\
\hline & & VH-97-35 & 04.04 .1997 & $48^{\circ} 09.23^{\prime} \mathrm{N}$ & $6^{\circ} 41.29^{\prime} \mathrm{W}$ & 150 & Van Veen grab \\
\hline & & VH-97-36 & 04.04 .1997 & $47^{\circ} 51.95^{\prime} \mathrm{N}$ & $6^{\circ} 57.05^{\prime} \mathrm{W}$ & 170 & Van Veen grab \\
\hline & & VH-97-37 & 04.04 .1997 & $47^{\circ} 32.94^{\prime} \mathrm{N}$ & $7^{\circ} 14.99^{\prime} \mathrm{W}$ & 467 & Van Veen grab \\
\hline & & VH-97-49 & 05.04 .1997 & $47^{\circ} 33.21^{\prime} \mathrm{N}$ & $7^{\circ} 14.45^{\prime} \mathrm{W}$ & 340 & Van Veen grab \\
\hline & & VH-97-50 & 05.04 .1997 & $47^{\circ} 34.43^{\prime} \mathrm{N}$ & $7^{\circ} 13.10^{\prime} \mathrm{W}$ & 191 & Van Veen grab \\
\hline & \multirow{4}{*}{$\begin{array}{c}\text { RV } \\
\text { Belgica } \\
\text { 2008/12a }\end{array}$} & BG0812a-02 & 08.05 .2008 & $47^{\circ} 47.94^{\prime} \mathrm{N}$ & $6^{\circ} 54.48^{\prime} \mathrm{W}$ & 128 & $\begin{array}{l}\text { NIOZ Haja box } \\
\text { corer }\end{array}$ \\
\hline & & BG0812a-05 & 10.05 .2008 & $48^{\circ} 12.06^{\prime} \mathrm{N}$ & $7^{\circ} 35.88^{\prime} \mathrm{W}$ & 177 & $\begin{array}{c}\text { NIOZ Haja box } \\
\text { corer }\end{array}$ \\
\hline & & BG0812a-06 & 09.05 .2008 & $47^{\circ} 53.94^{\prime} \mathrm{N}$ & $7^{\circ} 53.88^{\prime} \mathrm{W}$ & 450 & $\begin{array}{l}\text { NIOZ Haja box } \\
\text { corer }\end{array}$ \\
\hline & & BG0812a-08 & 11.05 .2008 & $48^{\circ} 29.76^{\prime} \mathrm{N}$ & $8^{\circ} 30.18^{\prime} \mathrm{W}$ & 151 & $\begin{array}{l}\text { NIOZ Haja box } \\
\text { corer }\end{array}$ \\
\hline & FS Thalia & $\mathrm{D} 78 / 95$ & 29.10 .1995 & $48^{\circ} 30.97^{\prime} \mathrm{N}$ & $5^{\circ} 57.81^{\prime} \mathrm{W}$ & 119 & Van Veen grab \\
\hline $\begin{array}{l}\text { Murray et } \\
\text { al. (1982) }\end{array}$ & unknown & $12 / 97$ & $08 .-13.10 .1979$ & $49^{\circ} 10^{\prime} \mathrm{N}$ & $6^{\circ} 59^{\prime} \mathrm{W}$ & 122 & Shipek grab \\
\hline \multirow{4}{*}{$\begin{array}{l}\text { Sturrock } \\
\text { and } \\
\text { Murray } \\
(1981)\end{array}$} & \multirow{4}{*}{ unknown } & $3 / 13$ & & $48^{\circ} 41^{\prime} \mathrm{N}$ & $6^{\circ} 56^{\prime} \mathrm{W}$ & 145 & Shipek grab \\
\hline & & $18 / 166$ & spring/autumn & $48^{\circ} 22^{\prime} \mathrm{N}$ & $6^{\circ} 09^{\prime} \mathrm{W}$ & 145 & Shipek grab \\
\hline & & $17 / 152$ & 1977-1979 & $48^{\circ} 21^{\prime} \mathrm{N}$ & $6^{\circ} 59^{\prime} \mathrm{W}$ & 176 & Shipek grab \\
\hline & & $1 / 1$ & & $48^{\circ} 20^{\prime} \mathrm{N}$ & $7^{\circ} 32^{\prime} \mathrm{W}$ & 170 & Shipek grab \\
\hline \multirow{3}{*}{$\begin{array}{l}\text { Schönfeld } \\
\text { and } \\
\text { Altenbach } \\
(2005)\end{array}$} & \multirow{3}{*}{$\begin{array}{c}\text { FS } \\
\text { Poseidon } \\
201\end{array}$} & PO201/10-753 & 04.07 .1994 & $47^{\circ} 47.04^{\prime} \mathrm{N}$ & $7^{\circ} 45.90^{\prime} \mathrm{W}$ & 684 & USNEL box corer \\
\hline & & PO201/10-754 & 04.07.1994 & $47^{\circ} 54.18^{\prime} \mathrm{N}$ & $7^{\circ} 39.90^{\prime} \mathrm{W}$ & 398 & USNEL box corer \\
\hline & & PO201/10-755 & 04.07.1994 & $47^{\circ} 56.64^{\prime} \mathrm{N}$ & $7^{\circ} 37.92^{\prime} \mathrm{W}$ & 207 & USNEL box corer \\
\hline
\end{tabular}


Dorst, Figure 1

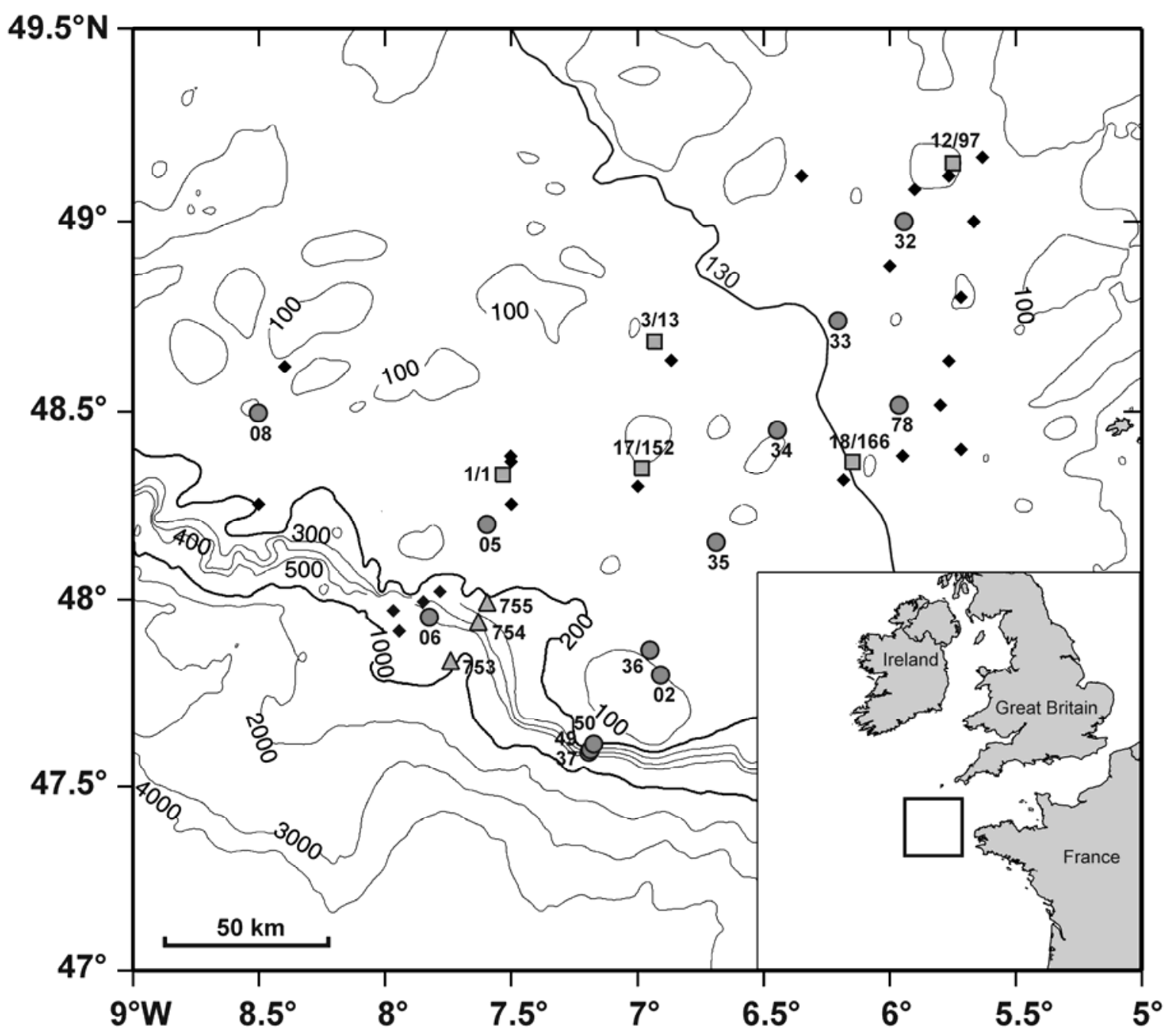


Dorst, Figure 2

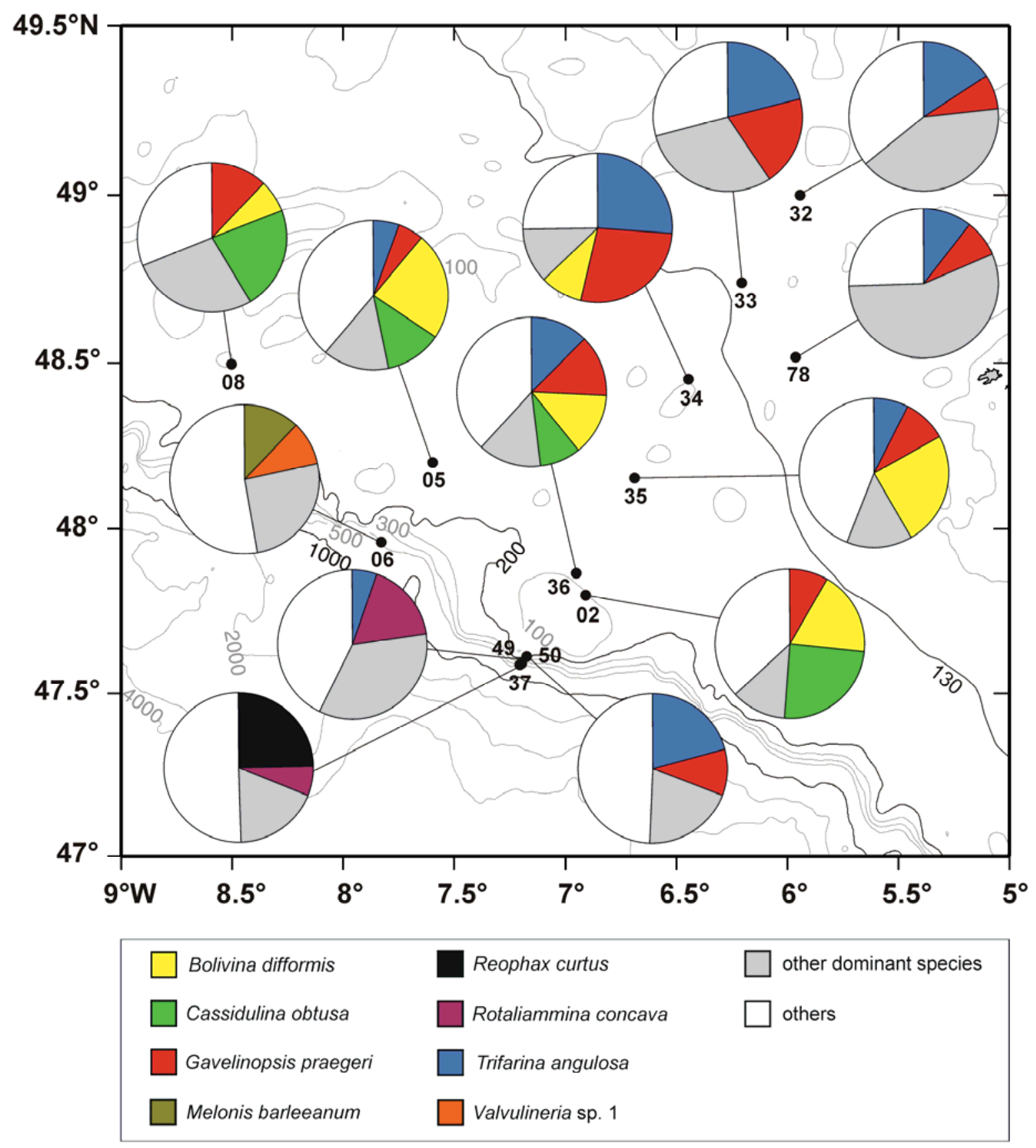




\section{Dorst, Figure 3}

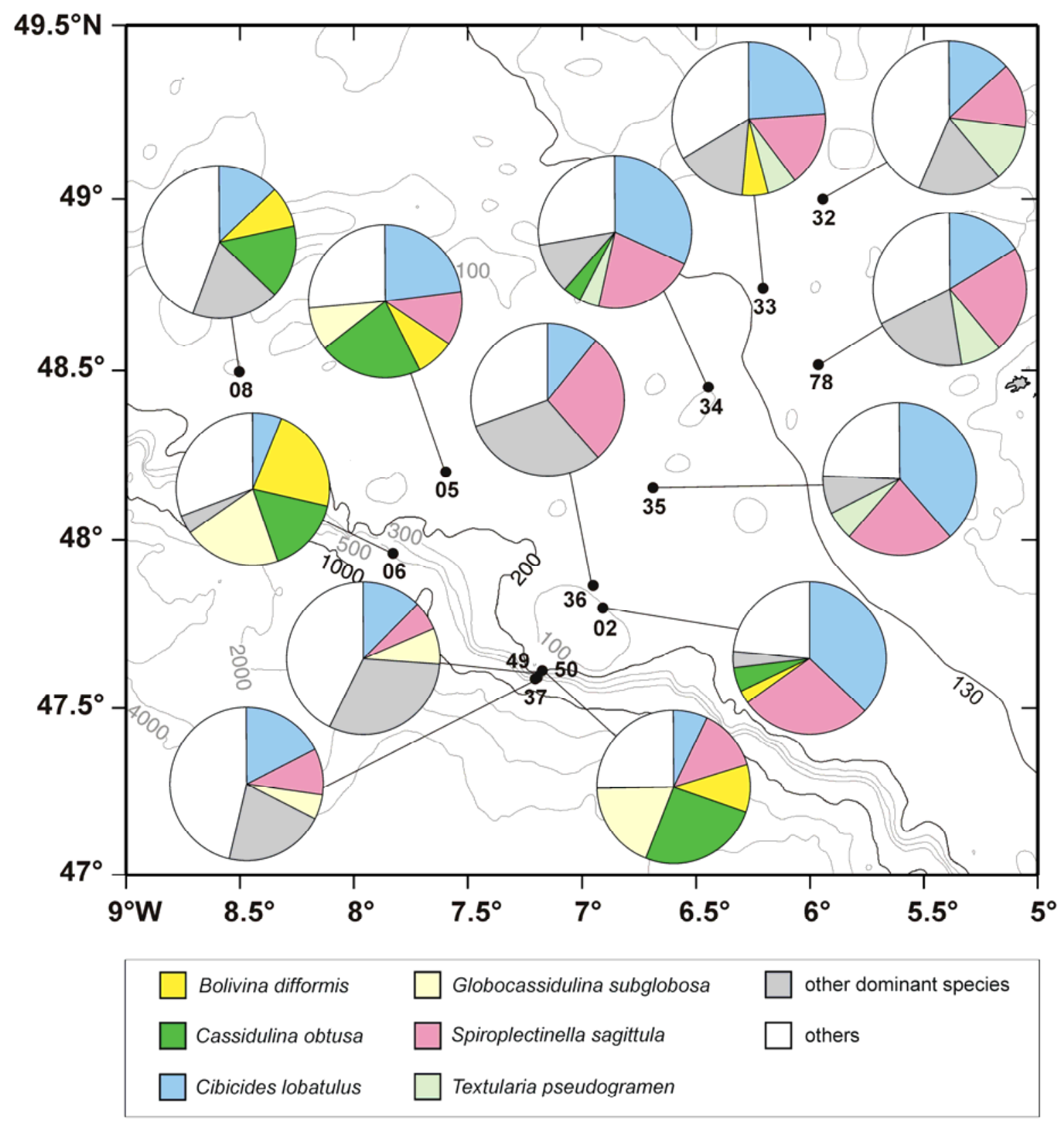




\section{Dorst, Figure 4a}

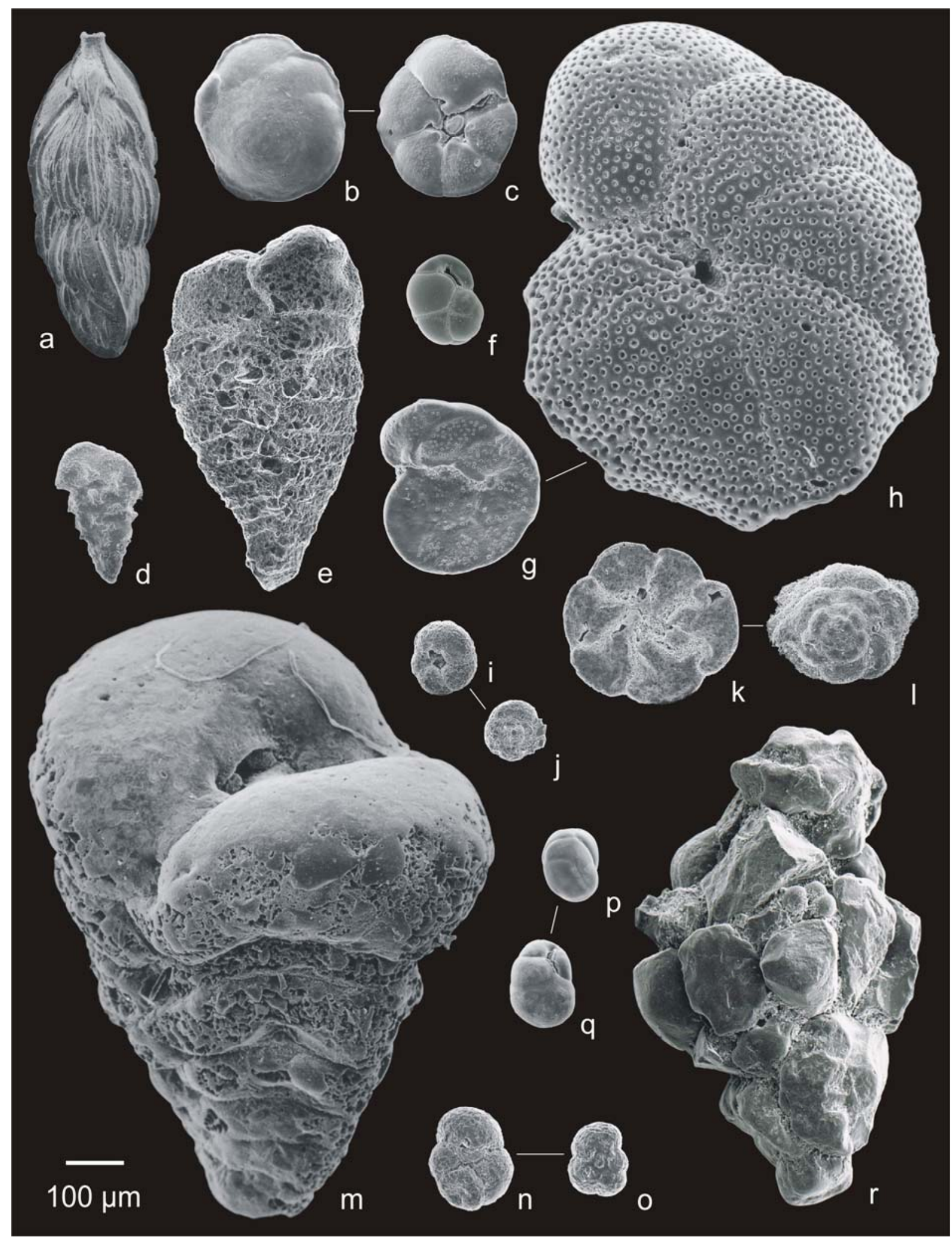




\section{Dorst, Figure 4b}

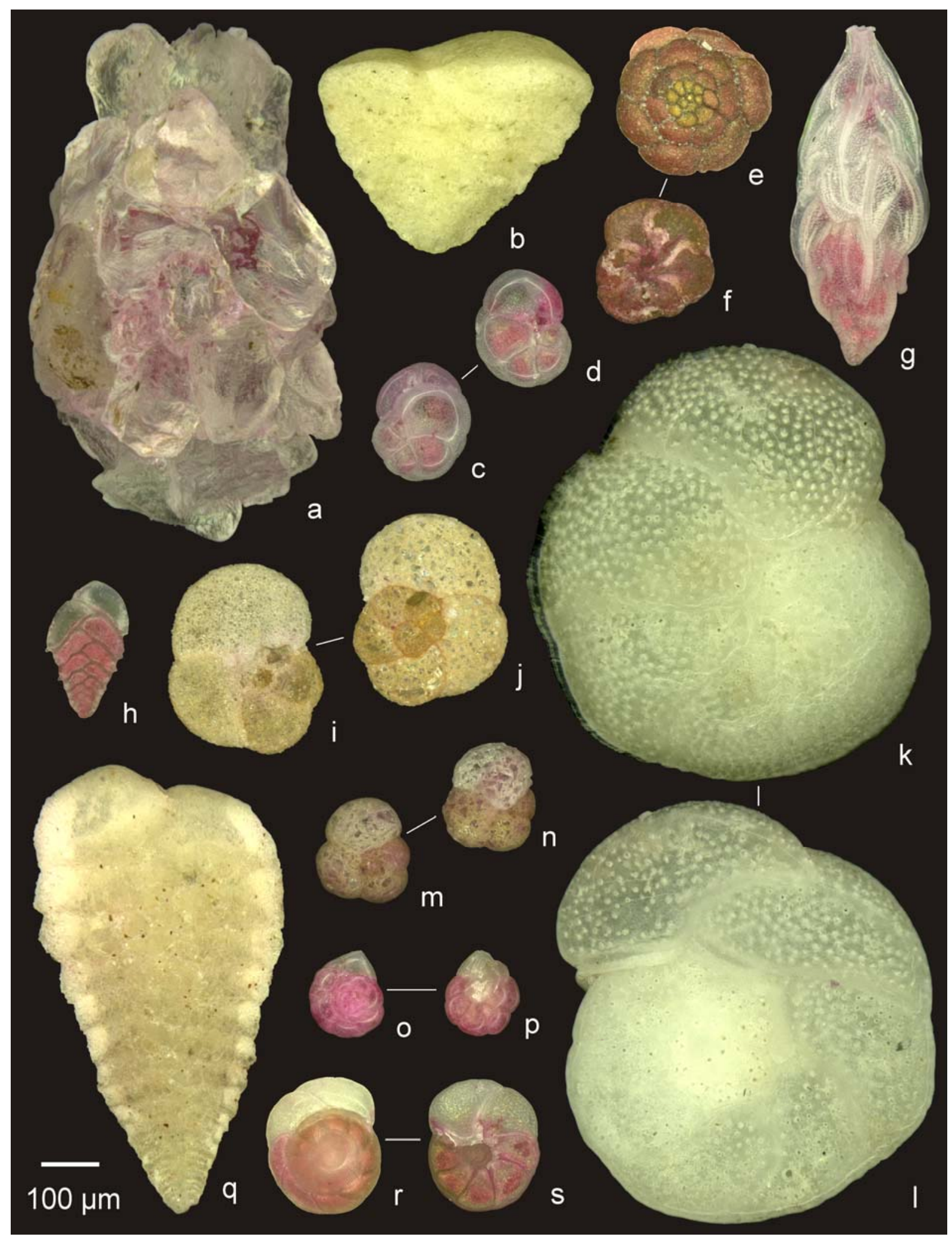


Dorst, Figure 5

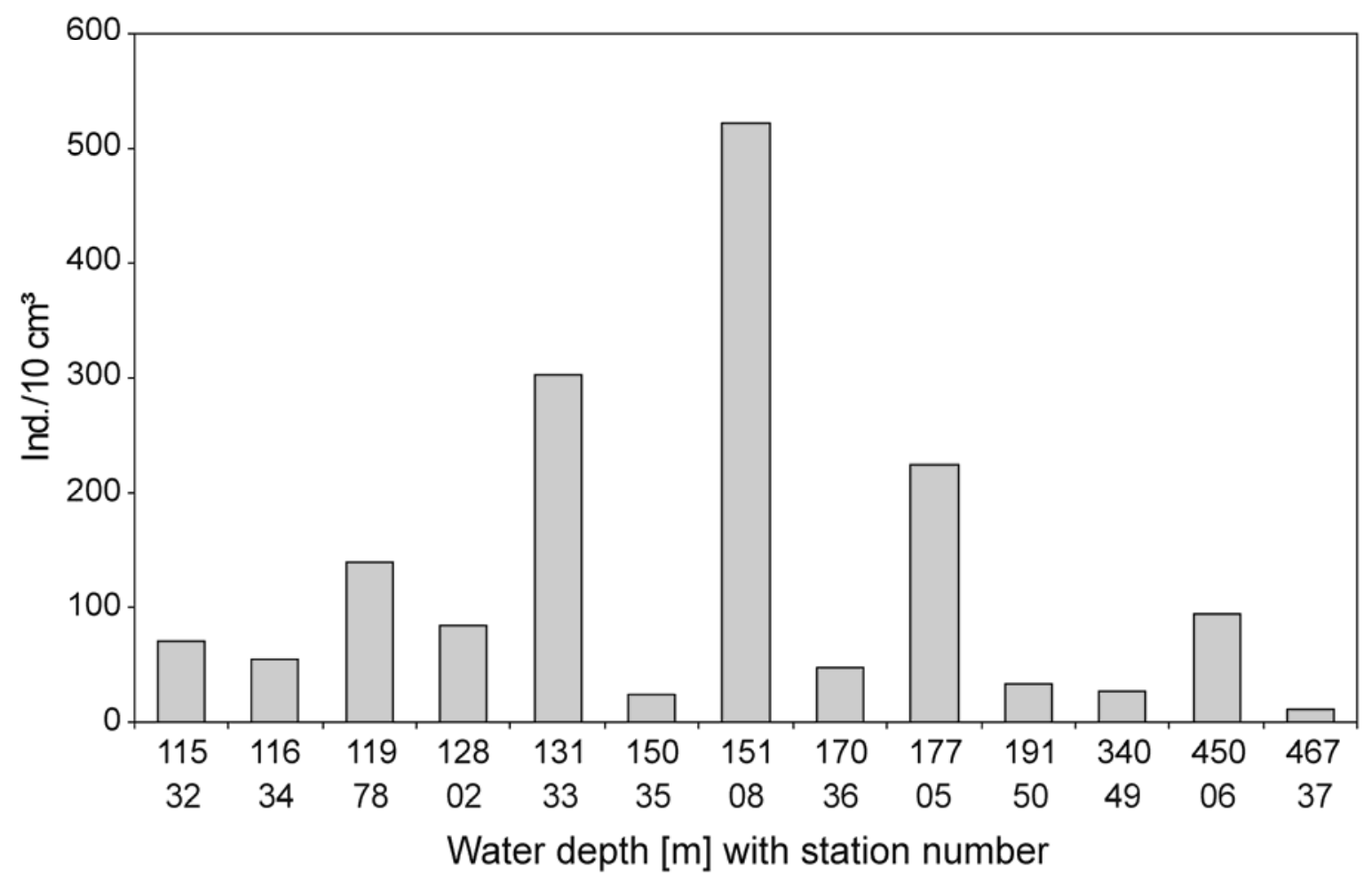

Dorst, Figure 6

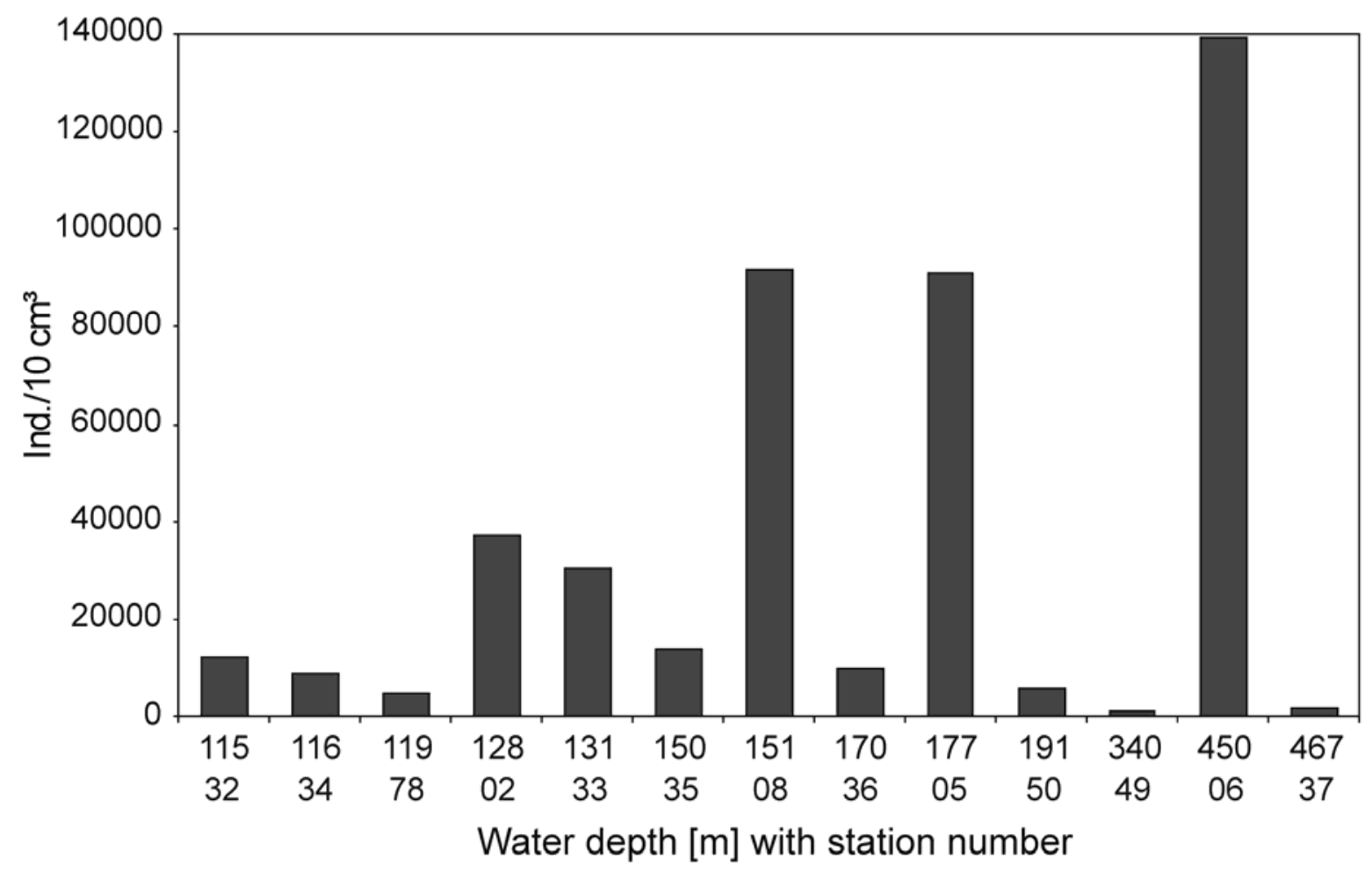


Dorst, Figure 7

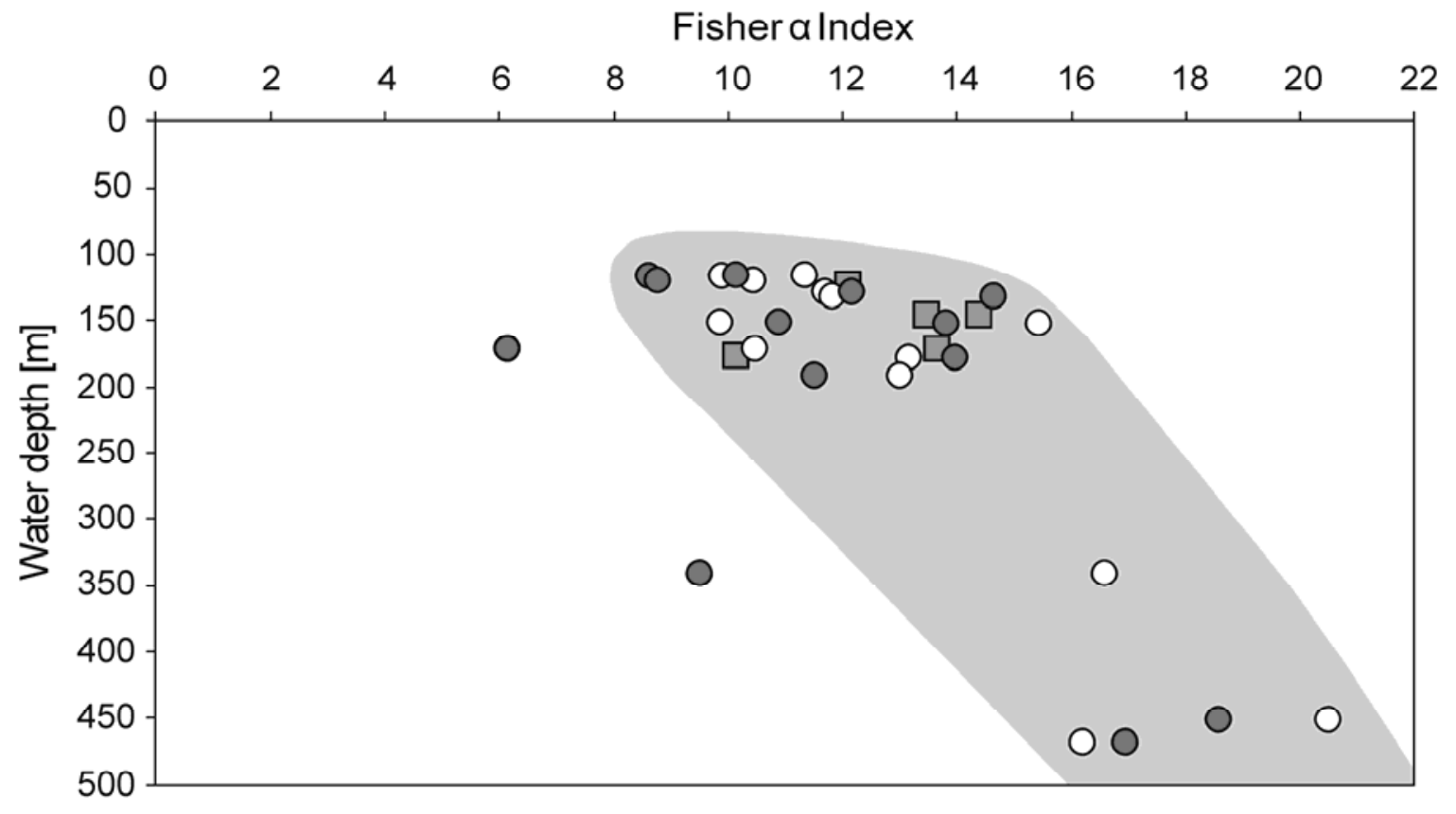

Dorst, Figure 8

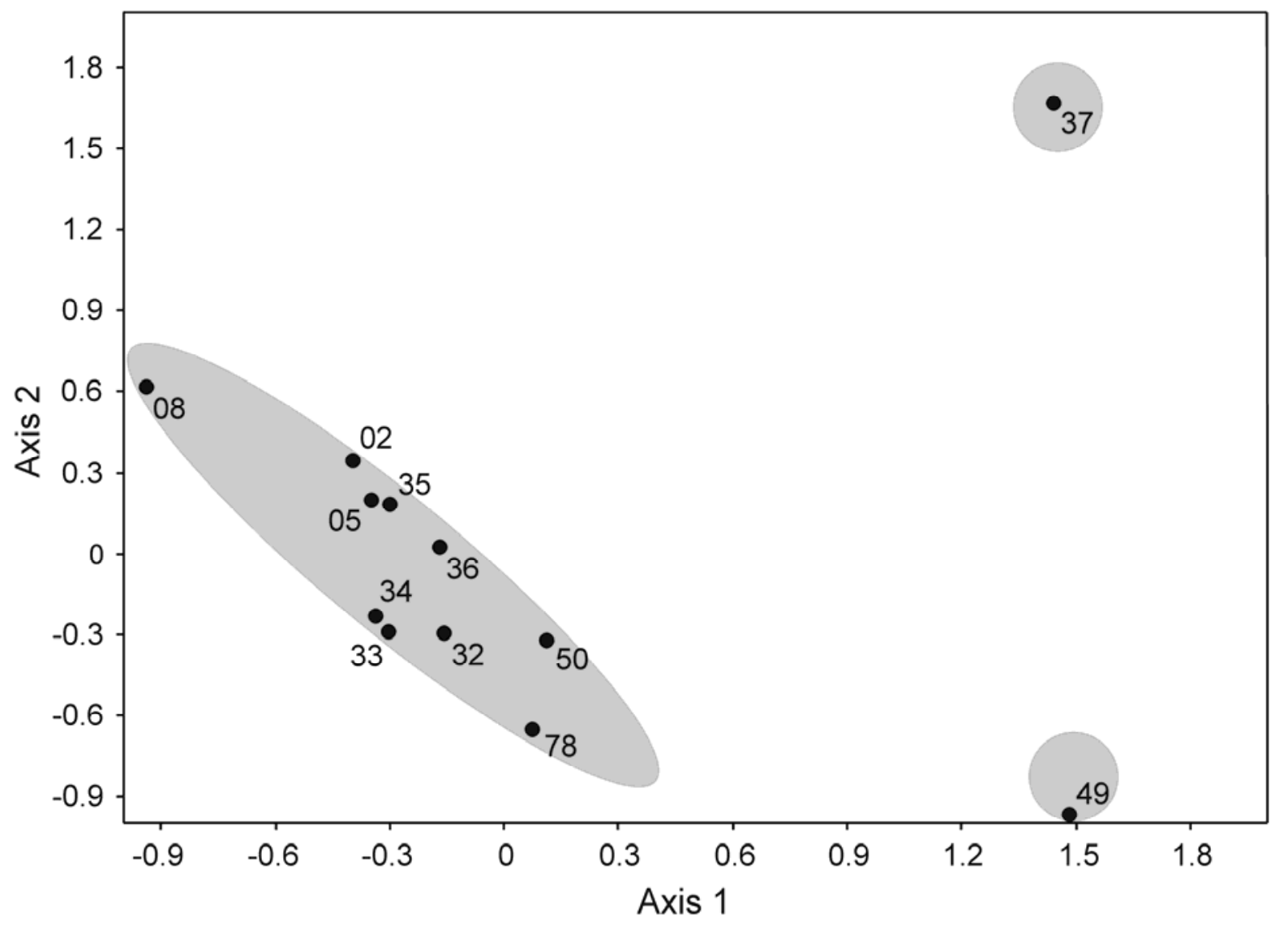


Dorst, Figure 9

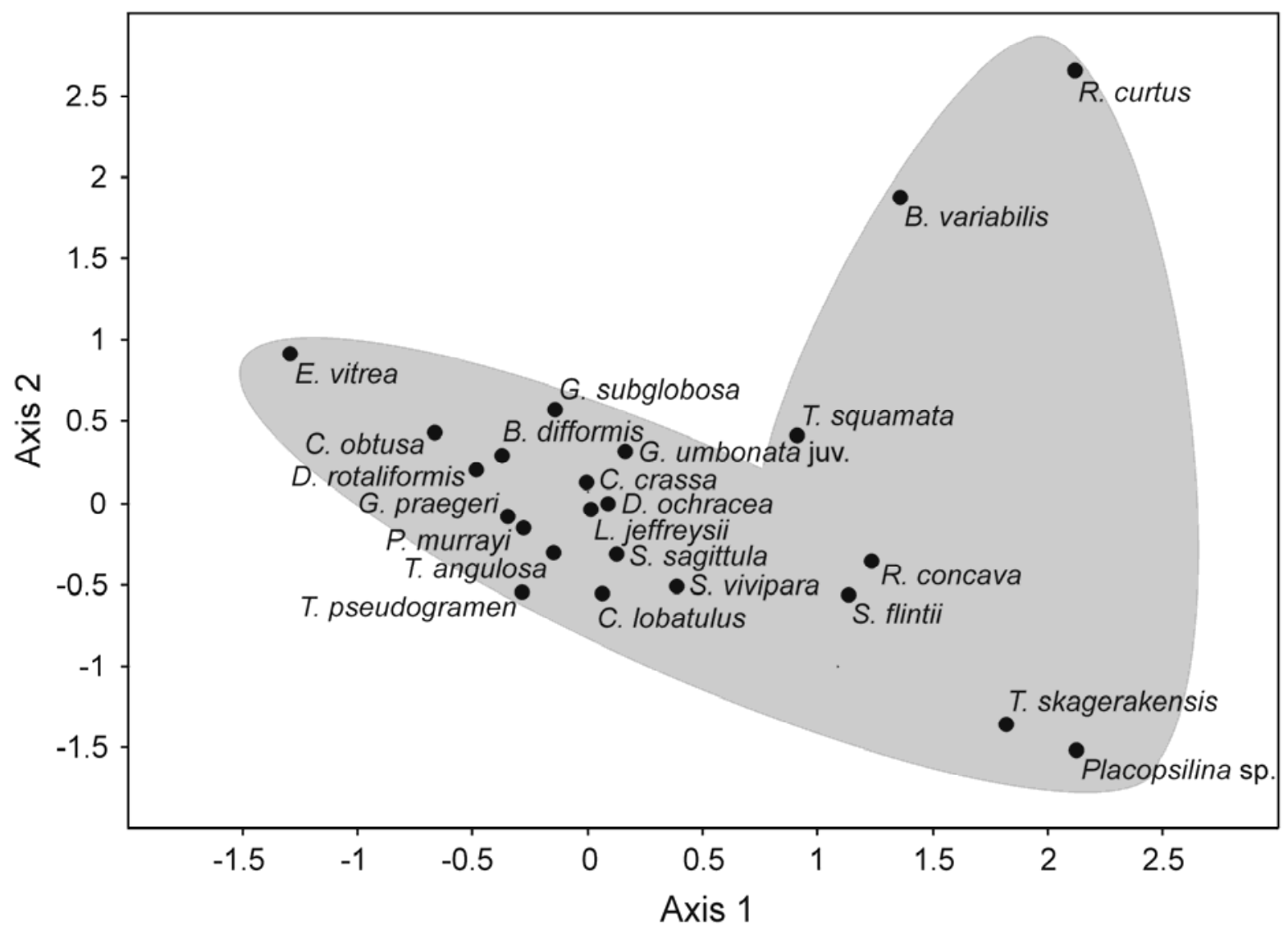


Dorst, Figure 10

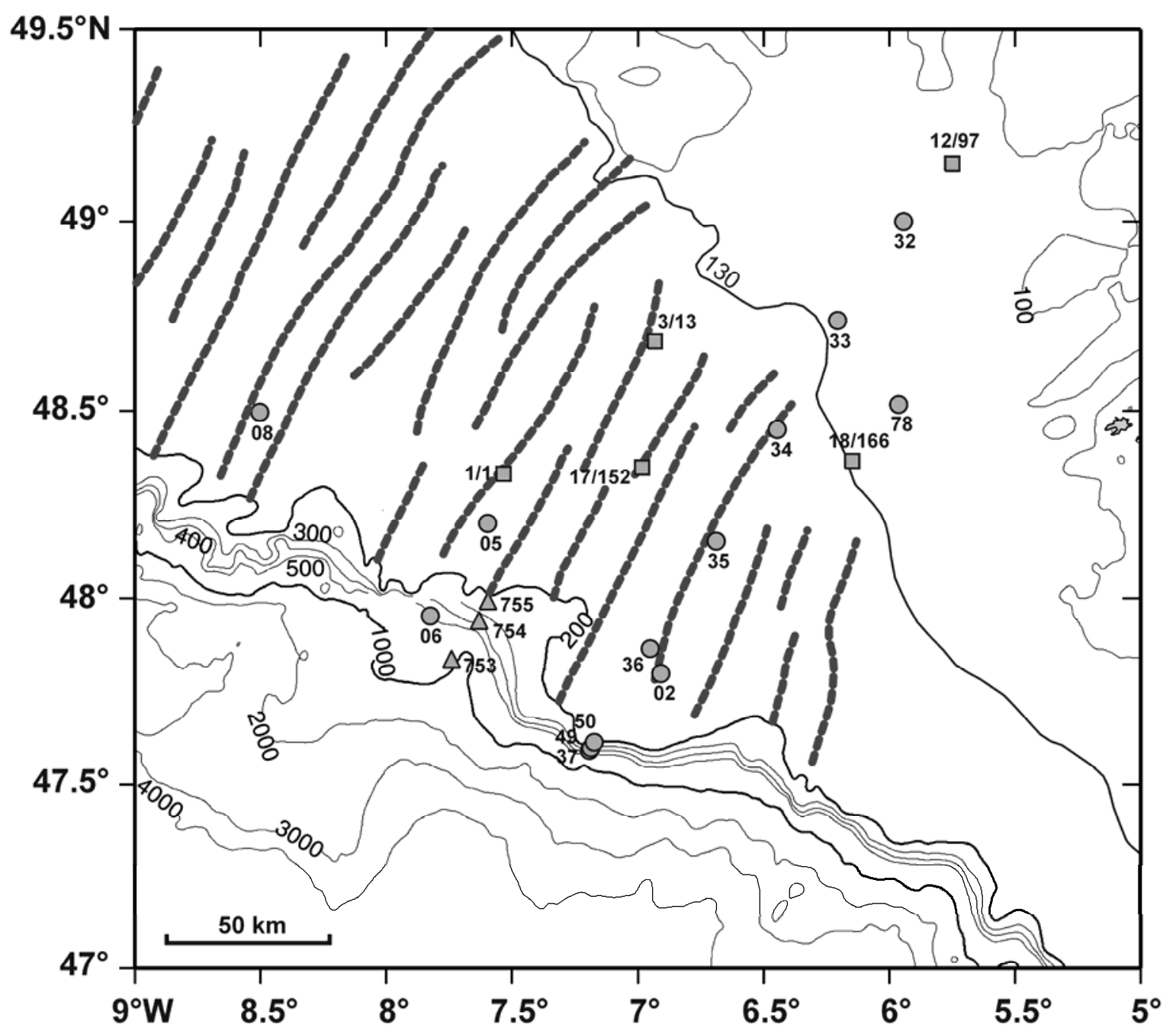

